\title{
Guidelines to Optimal Design of Furrow Irrigation Based on Plants, Soil and Furrow Specifications
}

\author{
Saeid Eslamian ${ }^{1}$, Kaveh Ostad-Ali-Askari ${ }^{{ }^{*}}$, Mahboubeh Amoushahi-Khouzani ${ }^{3}$, Maryam \\ Marani-Barzani ${ }^{4}$, Morteza Soltani ${ }^{5}$, Masoud Kazemi ${ }^{6}$, Amir Gandomkar ${ }^{7}$, Shahide \\ Dehghan $^{7}$, Nicolas R. Dalezios ${ }^{8}$,Vijay P. Singh ${ }^{9}$,Yohannes Yihdego ${ }^{10}$, Foroozan Rajaei-Rizi ${ }^{11}$, \\ Hossein Norouzi ${ }^{12}$, Hamid-Reza Shirvani-Dastgerdi ${ }^{2}$, Arvin Jamshidi ${ }^{2}$, Arsalan Malekian ${ }^{2}$, \\ Zahra Majidifar ${ }^{13}$, Mohsen Ghane ${ }^{14}$, \\ ${ }^{I}$ Department of Water Engineering, Isfahan University of Technology, Isfahan, Iran \\ ${ }^{2 *}$ Department of Civil Engineering, Isfahan (Khorasgan) Branch, Islamic Azad University, Isfahan, Iran \\ ${ }^{3}$ Water Engineering Department, Science and Research Branch, Islamic Azad University, Tehran, Iran \\ ${ }^{4}$ Department of Geography, University of Malaya (UM), 50603 Kuala Lumpur, Malaysia \\ ${ }^{5}$ Department of Architectural Engineering, Shahinshahr Branch, Islamic Azad University, Shahinshahr, Iran \\ ${ }^{6}$ Civil Engineering Department, Najafabad Branch, Islamic Azad University, Najafabad, Iran \\ ${ }^{7}$ Department of Geography, Najafabad Branch, Islamic Azad University, Najafabad, Iran \\ ${ }^{8}$ Laboratory of Hydrology, Department of Civil Engineering, University of Thessaly, Volos, Greece \& \\ Department of Natural Resources Development and Agricultural Engineering, Agricultural University of \\ Athens, Athens, Greece. \\ ${ }^{9}$ Department of Biological and Agricultural Engineering \& Zachry Department of Civil Engineering, Texas A \\ and M University, 321 Scoates Hall, 2117 TAMU, College Station, Texas 77843-2117, U.S.A. \\ ${ }^{10}$ Snowy Mountains Engineering Corporation (SMEC), Sydney, New South Wales 2060, Australia. Geo- \\ Information Science and Earth Observation (ITC), University of Twente, the Netherlands \\ ${ }^{11}$ Water Engineering Department, Shahrekord University, Shahrekord, Iran \\ ${ }^{12}$ Department of Civil Engineering, Maybod Branch, Islamic Azad University, Maybod, Yazd, Iran. \\ ${ }^{13}$ Department of Agronomy and Plant Breeding, Lorestan University, Lorestan, Iran \\ ${ }^{14}$ Civil Engineering Department, South Tehran Branch, Islamic Azad University,Tehran,Iran
}

*Corresponding Author: Dr. Kaveh Ostad-Ali-Askari, Department of Civil Engineering, Isfahan (Khorasgan) Branch, Islamic Azad University, Isfahan, Iran. Email: Koa.askari@khuisf.ac.ir

\begin{abstract}
In order to optimize the usage of water in agriculture, it is necessary to increase the efficiency of irrigation systems, especially those of surface irrigation. One of the steps to be made to achieve this goal is the optimal design of surface irrigation. It this article the design variables of furrow irrigation, that includes length of furrow, inflow rate and irrigation time (time of cut-off), were calculated to minimize the irrigation costs, the objective function, and to obtain a maximum application efficiency. The objective function encompasses water, labor, head ditch and furrow digging (ditch constructions) costs. Labor cost is irrigation time's function and the latter is dependent on water advance period in the furrows. Therefore, it is necessary for the objective function to apply explicit and accurate equation in order to calculate time of advance. Because in none of the accurate methods for furrow irrigation design, such as zero-inertia modeling, the advance time is explicitly calculated, therefore in this research the equation obtained by Valiantzas, which he extracted from the results of zero-inertia modeling, was used. In the objective function in addition to the design variables the specifications of soil, furrow and net irrigation requirement also exist. Therefore, it is possible to calculate design variables and afterwards the irrigation efficiency for different soil types and plant types. In this article this task was performed with different soil types and in accordance with different requirements for irrigation and the results are presented in the tables.
\end{abstract}

Keywords: Furrow Irrigation, Advance Time, Optimization 


\section{INTRODUCTION}

One of the most effective steps towards increasing the efficiency of the surface irrigation is design optimization. Generally, we can divide the methods of surface irrigation design or methods for time of advance calculation (an important parameter in design) into three groups presented below:

1. Simple methods such as SCS. Valiantzas (2001) have shown that by using this method significant errors in calculating the time of advance were detected. Reddy and Clyma (1981) and Reddy and Apolayo (1991) have used SCS equation for a furrow optimal design and they have considered total cost of irrigation as their objective.

2. Ordinary methods such as kinematic wave model, zero-inertia model and dynamic wave model. First of all, these methods are complicated, and secondarily, it is not possible by using them to calculate explicit time of advance. Strelkoff and Katapodes (1977) and Elliott and others (1982) held the method of zero-inertia modeling to be suitable to calculate the time of advance [1-16].

3. Volume balance models. First of all, in these models it is assumed that the coefficients of the surface flow and subsurface flow during the whole period of advance time stay constant, and secondarily, these methods are dependent on normal depth. Walker and Skogerboe (1987) used the volume balance models to calculate time of advance.

In order to optimize furrow irrigation none of the aforementioned methods were suitable, because by using those it is not possible to calculate the explicit and accurate time of advance. Optimal design requires a mathematical equation to explicitly calculate the time of advance necessary for the objective function. In the research presented in the present article total cost necessary for one irrigation session including labor, water and ditch construction is considered to be the functional objective that needs to be minimized. It is clear that labor cost is a function of irrigation time and the latter is a function of advance time. Considering the weak points of the aforementioned methods, in this research the equation introduced by Valiantzas (2001) was used to calculate the time of advance. This is an explicit equation for advance time calculation that Valiantzas obtained it from the results of zero-inertia modeling and it is having a high accuracy [17-37].

\section{Material AND MethodS}

In order to irrigate a given piece of a farmland by the method of furrow irrigation it is necessary to divide it into several irrigationsection. Each of the irrigation sections contains a certain number of furrows that are being irrigated simultaneously. Valiantzas (2001) presented an equation to calculate total cost of one irrigation session of a farmland that this equation has been changed by Shayannejad (2004) in the following way:

$$
C_{t}=\frac{W_{f} \cdot L_{f} \cdot Q_{0} \cdot T_{c o}}{W \cdot L}\left(C_{w}+\frac{C_{l}}{Q_{t}}\right)+\frac{W_{f} \cdot L_{f}}{N_{i}}\left(\frac{C_{f}}{W}+\frac{C_{d}}{L}\right)
$$

Where regarding the above:

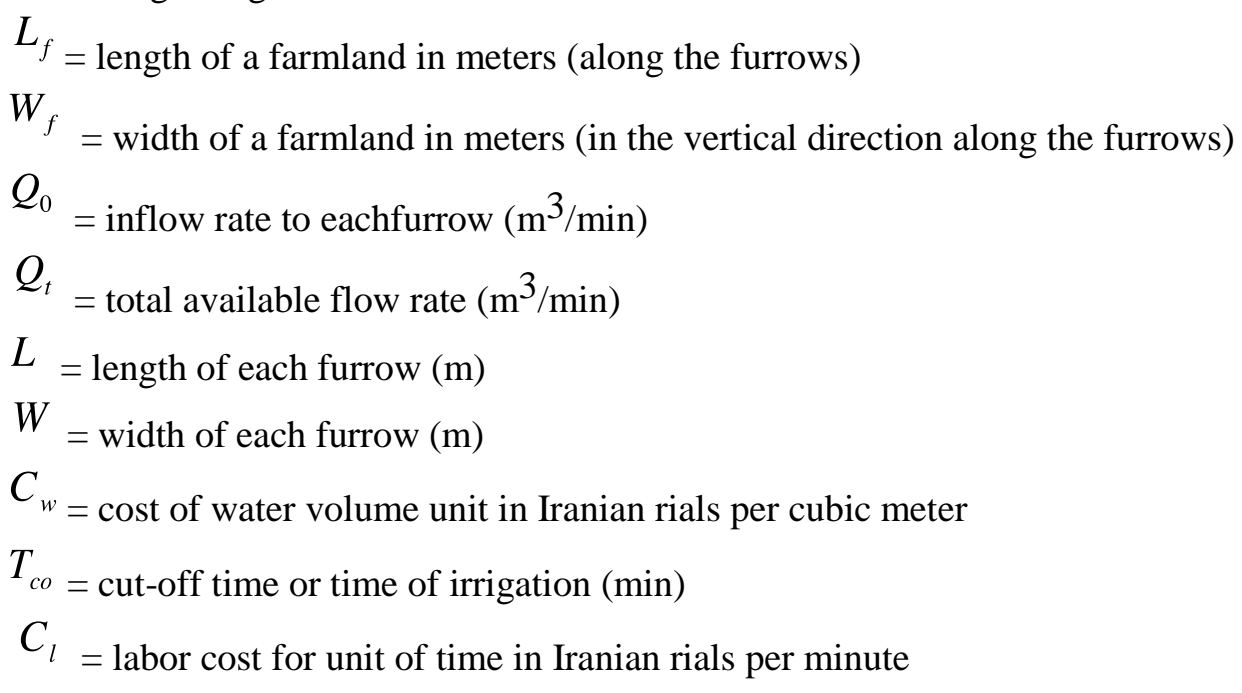




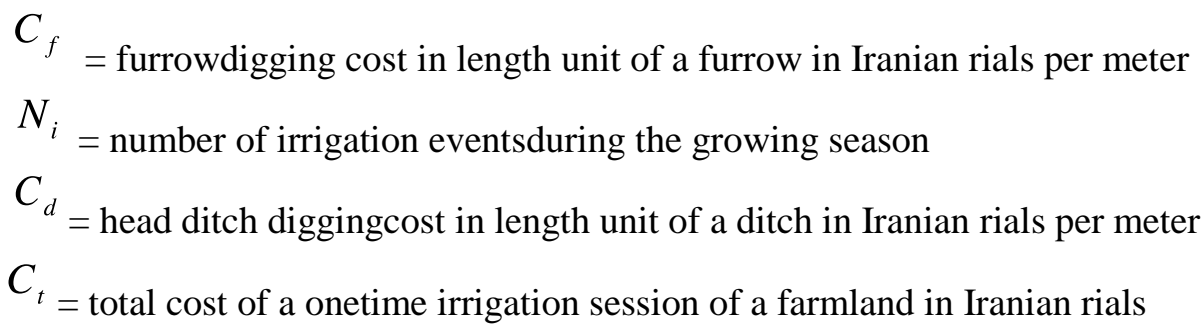

Equation (1) indicates that total cost of the objective function is formed by the the three ${ }^{,} Q_{0}, T_{c o}, L$ variables, and can be written as a function of the two other variables. In order to do that, at first this addition is being written:

$T_{c o}=T_{l}+T_{r}$

Where regarding the above:

$T_{l}=$ water advance time to the end of a furrow (min)

$T_{r}=$ time of intake opportunity according to net irrigation requirement ( $\mathrm{min}$ )

In order to calculate $T_{r}$ we can use any of the infiltration equations. If Kostiakov's equation is to be used, the calculation is as follows:

$$
Z=K . T^{\alpha}
$$

$$
T_{r}=\left(\frac{Z_{r}}{K}\right)^{1 / \alpha}
$$

Where regarding the above:

$Z$ = depth of the percolated (infiltrated) water (m)

$T=$ percolation (infiltration) time ( $\mathrm{min})$

$Z_{r}=$ net irrigation requirement $(\mathrm{m})$

$K, \alpha=$ infiltration coefficients of Kostiakov's equation

To calculate $T_{l}$ the equation presented by Valiatzas (2001) is used:

$$
T_{l}=(1+0 \cdot 15 \alpha) \cdot L \cdot A_{0} / Q_{0}+\left(\sigma_{z} \cdot K \cdot L / Q_{0}\right)^{1 /(1-\alpha)}
$$

Where regarding the above:

$A_{0}=$ area of cross section at the end of upstream of the furrow $\left(\mathrm{m}^{2}\right)$

$\sigma_{z}=$ subsurface flow shape factor. This coefficient is calculated by the following equation:

$$
\sigma_{z}=\frac{\alpha \pi \cdot(1-\alpha)}{\operatorname{Sin}(\alpha \pi)}
$$

$A_{0}$ value is calculated by using Manning's equation where the furrow form coefficients are calculated it the following way:

$$
A_{0}=\left(\frac{n^{2} Q_{0}{ }^{2}}{3600 S_{0} . \rho_{1}}\right)^{1 / \rho_{2}}
$$


Where regarding the above:

$n$ = Manning's roughness coefficient

$S_{0}$ = furrow bed slope $(\mathrm{m} / \mathrm{m}$, in decimal form)

$\rho_{1}, \rho_{2}=$ furrow shape coefficients. These coefficients in accordance with Manning's equation are calculated as follows:

$$
A \cdot R^{4 / 3}=\rho_{1} A^{\rho_{2}}
$$

Where regarding the above:

$A=$ flow cross section $\left(\mathrm{m}^{2}\right)$

$R=$ Hydraulic radius $(\mathrm{m})$

Finally, by substituting the (2), (4), and (5) equations in the equation (1), the equation is obtained indicating that $C_{t}$ is a function of the two $Q_{0}$ and $L$ variables. This equation can be written as follows:

$$
C_{t}=f\left(Q_{0}, L\right)
$$

if $L$ is assumed to be constant and derivative equation (9) in respect to $Q_{0}$ was made equal to zero, the value of inflow rate that leads to minimum cost is obtained by the following:

$$
\begin{aligned}
& C_{1} \cdot Q_{0}^{2 / \rho_{2}-1}-C_{2} \cdot Q_{0}^{1 /(\alpha-1)}+T_{r}=0 \\
& C_{1}=\left(\frac{n^{2}}{\rho_{1} S_{0}}\right)^{1 / \rho_{2}}\left(\frac{2 L}{\rho_{2}}\right)(1+0.15 \alpha) \\
& C_{2}=\frac{\alpha}{(1-\alpha)\left(\sigma_{z} K L\right)^{1 /(1-\alpha)}}
\end{aligned}
$$

Afterwards by using equation (2) it is possible to calculate irrigation time and by using

$$
E_{a}=\frac{Z_{r} \cdot W \cdot L}{Q_{0} \cdot T_{c o}} \times 100
$$

Formula to calculate irrigation efficiency,

Where regarding the above $E_{a}$ is irrigation efficiency percentage. According to the equation (1) along with the minimization of $C_{t}$ results of $Q_{c}, T_{c o}$ are also minimized. Therefore, in respect to the equation (13) the irrigation efficiency is maximized [38-98].

To summarize it is possible to say, that the method described in this research is based on principal of cost minimization and irrigation efficiency maximization and is a result of the calculations related to inflow rate to furrow, length of furrow, irrigation time and irrigation efficiency. In order to check length of furrow variables, the above method was solved by using furrows of different length, and for each of the lengths an inflow rate in accordance with a particular length is obtained [99-204].

\section{CONCLUSiOn AND Result}

As for example, the equation's solution and results (10) for the furrow having the following specifications (an ordinary furrow), with taking into account various values of furrow length, irrigation requirements and soil patterns (with Intake Family or IF standard) and being in accordance with the Newton-Raphson method are provided in the tables below. 


$$
n=0.01 \quad, \quad S_{0}=0.001 \quad, \quad \rho_{1}=0.6 \quad, \quad \rho_{2}=2.8
$$

The data presented in the ordinary tables of furrow irrigation design (provided by Boucher) differ from the data provided in the following tables. In addition to this in the last table information related to the form of a furrow is included. It is necessary to mention that numbers in the following tables are numbers of inflow rates to a furrow. These numbers should not exceed erosion inflow rates to a furrow.

\begin{tabular}{|c|c|c|c|c|c|c|c|c|c|}
\hline \multirow{2}{*}{$\begin{array}{l}\mathrm{IF}=0.1 \\
\mathrm{~L}(\mathrm{~m})\end{array}$} & \multicolumn{3}{|c|}{ Qo(lit/s) } & \multicolumn{3}{|c|}{$\mathrm{IF}=0.3$} & \multicolumn{2}{|l|}{ Qo(lit/s) } & \multirow[b]{2}{*}{$\mathrm{Zr}=.125 \mathrm{~m}$} \\
\hline & $\mathrm{Zr}=.05 \mathrm{~m}$ & $\mathrm{Zr}=.075 \mathrm{~m}$ & $\mathrm{Zr}=.1 \mathrm{~m}$ & $\mathrm{Zr}=.125 \mathrm{~m}$ & $\mathrm{~L}(\mathrm{~m})$ & $\mathrm{Zr}=.05 \mathrm{~m}$ & $\mathrm{Zr}=.075 \mathrm{~m}$ & $\mathrm{Zr}=.1 \mathrm{~m}$ & \\
\hline & 0.02 & 0.01 & 0.01 & 0.01 & 20 & 0.07 & 0.06 & 0.05 & \\
\hline 30 & 0.03 & 0.02 & 0.01 & 0.01 & 30 & 0.1 & 0.08 & 0.07 & 0.06 \\
\hline 40 & 0.03 & 0.02 & 0.02 & 0.02 & 40 & 0.14 & 0.11 & 0.09 & 0.08 \\
\hline 50 & 0.04 & 0.03 & 0.02 & 0.02 & 50 & 0.18 & 0.13 & 0.11 & 0.1 \\
\hline 60 & 0.05 & 0.04 & 0.03 & 0.02 & 60 & 0.23 & 0.17 & 0.14 & 0.12 \\
\hline 70 & 0.06 & 0.04 & 0.03 & 0.03 & 70 & 0.26 & 0.2 & 0.16 & 0.14 \\
\hline 80 & 0.06 & 0.05 & 0.04 & 0.03 & 80 & 0.3 & 0.23 & 0.2 & 0.16 \\
\hline 90 & 0.07 & 0.05 & 0.04 & 0.03 & 90 & 0.33 & 0.25 & 0.22 & 0.2 \\
\hline 100 & 0.08 & 0.06 & 0.05 & 0.04 & 100 & 0.36 & 0.3 & 0.24 & 0.22 \\
\hline 110 & 0.1 & 0.06 & 0.05 & 0.04 & 110 & 0.4 & 0.33 & 0.27 & 0.24 \\
\hline 120 & 0.11 & 0.07 & 0.05 & 0.04 & 120 & 0.45 & 0.35 & 0.29 & 0.26 \\
\hline 130 & 0.11 & 0.07 & 0.06 & 0.05 & 130 & 0.49 & 0.38 & 0.31 & 0.28 \\
\hline 140 & 0.12 & 0.08 & 0.06 & 0.05 & 140 & 0.52 & 0.41 & 0.35 & 0.3 \\
\hline 150 & 0.13 & 0.08 & 0.07 & 0.05 & 150 & 0.56 & 0.44 & 0.37 & 0.32 \\
\hline 160 & 0.14 & 0.09 & 0.07 & 0.06 & 160 & 0.59 & 0.47 & 0.4 & 0.34 \\
\hline 170 & 0.14 & 0.09 & 0.07 & 0.06 & 170 & 0.63 & 0.49 & 0.42 & 0.36 \\
\hline 180 & 0.17 & 0.1 & 0.08 & 0.06 & 180 & 0.66 & 0.52 & 0.45 & 0.38 \\
\hline 190 & 0.18 & 0.12 & 0.08 & 0.07 & 190 & 0.69 & 0.55 & 0.47 & 0.42 \\
\hline 200 & 0.19 & 0.12 & 0.09 & 0.07 & 200 & 0.73 & 0.59 & 0.5 & 0.44 \\
\hline 210 & 0.2 & 0.13 & 0.09 & 0.07 & 210 & 0.76 & 0.62 & 0.52 & 0.46 \\
\hline 220 & 0.2 & 0.13 & 0.09 & 0.08 & 220 & 0.81 & 0.65 & 0.54 & 0.48 \\
\hline 230 & 0.21 & 0.14 & 0.1 & 0.08 & 230 & 0.85 & 0.68 & 0.57 & 0.5 \\
\hline 240 & 0.22 & 0.15 & 0.1 & 0.08 & 240 & 0.88 & 0.7 & 0.59 & 0.52 \\
\hline 250 & 0.23 & 0.15 & 0.1 & 0.09 & 250 & 0.92 & 0.73 & 0.61 & 0.54 \\
\hline 260 & 0.24 & 0.16 & 0.11 & 0.09 & 260 & 0.95 & 0.76 & 0.64 & 0.57 \\
\hline 270 & 0.25 & 0.16 & 0.11 & 0.09 & 270 & 0.99 & 0.79 & 0.66 & 0.59 \\
\hline 280 & 0.26 & 0.17 & 0.12 & 0.1 & 280 & 1.02 & 0.82 & 0.68 & 0.61 \\
\hline 290 & 0.26 & 0.17 & 0.14 & 0.1 & 290 & 1.06 & 0.85 & 0.71 & 0.63 \\
\hline 300 & 0.27 & 0.18 & 0.14 & 0.1 & 300 & 1.09 & 0.87 & 0.73 & 0.65 \\
\hline 310 & 0.28 & 0.18 & 0.15 & 0.11 & 310 & 1.12 & 0.9 & 0.77 & 0.67 \\
\hline 320 & 0.29 & 0.19 & 0.15 & 0.11 & 320 & 1.16 & 0.93 & 0.79 & 0.69 \\
\hline 330 & 0.31 & 0.19 & 0.15 & 0.11 & 330 & 1.19 & 0.96 & 0.82 & 0.71 \\
\hline 340 & 0.32 & 0.22 & 0.16 & 0.12 & 340 & 1.23 & 0.98 & 0.84 & 0.73 \\
\hline 350 & 0.33 & 0.22 & 0.16 & 0.12 & 350 & 1.26 & 1.01 & 0.87 & 0.75 \\
\hline 360 & 0.34 & 0.23 & 0.17 & 0.12 & 360 & 1.29 & 1.04 & 0.89 & 0.77 \\
\hline 370 & 0.35 & 0.24 & 0.17 & 0.13 & 370 & 1.33 & 1.07 & 0.91 & 0.79 \\
\hline 380 & 0.36 & 0.24 & 0.18 & 0.13 & 380 & 1.36 & 1.09 & 0.94 & 0.82 \\
\hline 390 & 0.37 & 0.25 & 0.18 & 0.15 & 390 & 1.39 & 1.12 & 0.96 & 0.84 \\
\hline 400 & 0.37 & 0.25 & 0.18 & 0.15 & 400 & 1.42 & 1.15 & 0.99 & 0.86 \\
\hline
\end{tabular}

Continued Table (1): Guide to the design of furrow irrigation

\begin{tabular}{|c|c|c|c|c|c|c|c|c|c|}
\hline $\mathrm{IF}=0.5$ & & Qo(lit/s) & & & $\mathrm{IF}=0.8$ & & Qo(lit/s) & & \\
\hline $\mathrm{L}(\mathrm{m})$ & $\mathrm{Zr}=.05 \mathrm{~m}$ & $\mathrm{Zr}=.075 \mathrm{~m}$ & $\mathrm{Zr}=.1 \mathrm{~m}$ & $\mathrm{Zr}=.125 \mathrm{~m}$ & $\mathrm{~L}(\mathrm{~m})$ & $\mathrm{Zr}=.05 \mathrm{~m}$ & $\mathrm{Zr}=.075 \mathrm{~m}$ & $\mathrm{Zr}=.1 \mathrm{~m}$ & $\mathrm{Zr}=.125 \mathrm{~m}$ \\
\hline 20 & 0.12 & 0.1 & 0.09 & 0.09 & 20 & 0.22 & 0.19 & 0.17 & 0.15 \\
\hline 30 & 0.19 & 0.15 & 0.14 & 0.13 & 30 & 0.34 & 0.29 & 0.26 & 0.23 \\
\hline 40 & 0.27 & 0.22 & 0.18 & 0.17 & 40 & 0.45 & 0.39 & 0.35 & 0.32 \\
\hline 50 & 0.34 & 0.27 & 0.24 & 0.22 & 50 & 0.57 & 0.49 & 0.43 & 0.4 \\
\hline 60 & 0.4 & 0.34 & 0.29 & 0.26 & 60 & 0.68 & 0.58 & 0.53 & 0.48 \\
\hline 70 & 0.48 & 0.39 & 0.33 & 0.31 & 70 & 0.79 & 0.68 & 0.62 & 0.57 \\
\hline 80 & 0.54 & 0.45 & 0.38 & 0.35 & 80 & 0.89 & 0.79 & 0.7 & 0.65 \\
\hline 90 & 0.61 & 0.5 & 0.44 & 0.39 & 90 & 1.02 & 0.88 & 0.79 & 0.73 \\
\hline 100 & 0.67 & 0.55 & 0.49 & 0.43 & 100 & 1.13 & 0.98 & 0.87 & 0.81 \\
\hline 110 & 0.73 & 0.61 & 0.54 & 0.49 & 110 & 1.23 & 1.07 & 0.97 & 0.89 \\
\hline 120 & 0.79 & 0.67 & 0.59 & 0.53 & 120 & 1.34 & 1.17 & 1.06 & 0.97 \\
\hline 130 & 0.86 & 0.73 & 0.63 & 0.58 & 130 & 1.45 & 1.26 & 1.14 & 1.04 \\
\hline 140 & 0.94 & 0.78 & 0.68 & 0.62 & 140 & 1.55 & 1.35 & 1.23 & 1.12 \\
\hline 150 & 1 & 0.84 & 0.73 & 0.66 & 150 & 1.66 & 1.44 & 1.32 & 1.22 \\
\hline 160 & 1.06 & 0.89 & 0.77 & 0.71 & 160 & 1.78 & 1.55 & 1.4 & 1.3 \\
\hline 170 & 1.13 & 0.95 & 0.82 & 0.75 & 170 & 1.88 & 1.65 & 1.49 & 1.38 \\
\hline 180 & 1.19 & 1 & 0.88 & 0.79 & 180 & 1.99 & 1.74 & 1.57 & 1.46 \\
\hline 190 & 1.25 & 1.05 & 0.93 & 0.83 & 190 & 2.09 & 1.83 & 1.66 & 1.53 \\
\hline 200 & 1.31 & 1.11 & 0.98 & 0.88 & 200 & 2.2 & 1.93 & 1.74 & 1.61 \\
\hline 210 & 1.38 & 1.16 & 1.03 & 0.92 & 210 & 2.3 & 2.02 & 1.82 & 1.69 \\
\hline 220 & 1.44 & 1.21 & 1.07 & 0.96 & 220 & 2.4 & 2.11 & 1.91 & 1.77 \\
\hline 230 & 1.5 & 1.26 & 1.12 & 1 & 230 & 2.51 & 2.21 & 2.01 & 1.85 \\
\hline 240 & 1.56 & 1.31 & 1.17 & 1.06 & 240 & 2.61 & 2.3 & 2.09 & 1.93 \\
\hline 250 & 1.64 & 1.38 & 1.22 & 1.1 & 250 & 2.71 & 2.39 & 2.18 & 2.01 \\
\hline 260 & 1.7 & 1.44 & 1.26 & 1.15 & 260 & 2.81 & 2.48 & 2.26 & 2.08 \\
\hline 270 & 1.76 & 1.49 & 1.31 & 1.19 & 270 & 2.91 & 2.57 & 2.34 & 2.16 \\
\hline 280 & 1.82 & 1.54 & 1.36 & 1.23 & 280 & 3.03 & 2.66 & 2.43 & 2.24 \\
\hline 290 & 1.88 & 1.6 & 1.4 & 1.28 & 290 & 3.13 & 2.77 & 2.51 & 2.32 \\
\hline 300 & 1.94 & 1.65 & 1.45 & 1.32 & 300 & 3.23 & 2.86 & 2.6 & 2.39 \\
\hline 310 & 2.01 & 1.7 & 1.5 & 1.36 & 310 & 3.33 & 2.95 & 2.68 & 2.47 \\
\hline 320 & 2.07 & 1.76 & 1.54 & 1.41 & 320 & 3.43 & 3.04 & 2.76 & 2.56 \\
\hline 330 & 2.13 & 1.81 & 1.59 & 1.45 & 330 & 3.54 & 3.13 & 2.85 & 2.64 \\
\hline 340 & 2.19 & 1.86 & 1.64 & 1.49 & 340 & 3.64 & 3.22 & 2.93 & 2.72 \\
\hline 350 & 2.25 & 1.91 & 1.68 & 1.53 & 350 & 3.74 & 3.31 & 3.01 & 2.8 \\
\hline 360 & 2.31 & 1.96 & 1.73 & 1.58 & 360 & 3.83 & 3.4 & 3.1 & 2.88 \\
\hline 370 & 2.37 & 2.02 & 1.77 & 1.62 & 370 & 3.93 & 3.49 & 3.18 & 2.95 \\
\hline 380 & 2.43 & 2.07 & 1.84 & 1.66 & 380 & 4.03 & 3.58 & 3.26 & 3.03 \\
\hline 390 & 2.49 & 2.12 & 1.88 & 1.7 & 390 & 4.13 & 3.67 & 3.34 & 3.11 \\
\hline 400 & 2.54 & 2.17 & 1.93 & 1.75 & 400 & 4.23 & 3.76 & 3.42 & 3.19 \\
\hline
\end{tabular}


Guidelines to Optimal Design of Furrow Irrigation Based on Plants, Soil and Furrow Specifications

Continued Table (1): Guide to the design of furrow irrigation

\begin{tabular}{|c|c|c|c|c|c|c|c|c|c|}
\hline $\begin{array}{l}\mathrm{IF}=1 \\
\mathrm{~L}(\mathrm{~m})\end{array}$ & $\mathrm{Zr}=.05 \mathrm{~m}$ & $\begin{array}{c}\text { Qo(lit/s) } \\
\mathrm{Zr}=.075 \mathrm{~m}\end{array}$ & $\mathrm{Zr}=.1 \mathrm{~m}$ & $\mathrm{Zr}=.125 \mathrm{nh}$ & $\begin{array}{l}\mathrm{IF}=1.5 \\
\mathrm{~L}(\mathrm{~m})\end{array}$ & $\mathrm{Zr}=.05 \mathrm{~m}$ & $\begin{array}{c}\text { Qo(lit/s) } \\
\mathrm{Zr}=.075 \mathrm{~m}\end{array}$ & $\mathrm{Zr}=.1 \mathrm{~m}$ & $\mathrm{Zr}=.125 \mathrm{~m}$ \\
\hline 20 & 0.29 & 0.25 & 0.21 & 0.2 & 20 & 0.42 & 0.37 & 0.34 & 0.32 \\
\hline 30 & 0.43 & 0.37 & 0.34 & 0.32 & 30 & 0.64 & 0.56 & 0.52 & 0.48 \\
\hline 40 & 0.58 & 0.51 & 0.45 & 0.42 & 40 & 0.84 & 0.74 & 0.69 & 0.65 \\
\hline 50 & 0.72 & 0.63 & 0.58 & 0.52 & 50 & 1.04 & 0.94 & 0.86 & 0.81 \\
\hline 60 & 0.86 & 0.75 & 0.69 & 0.65 & 60 & 1.26 & 1.13 & 1.03 & 0.97 \\
\hline 70 & 1.01 & 0.89 & 0.8 & 0.75 & 70 & 1.46 & 1.31 & 1.21 & 1.13 \\
\hline 80 & 1.15 & 1.01 & 0.91 & 0.86 & 80 & 1.66 & 1.49 & 1.38 & 1.28 \\
\hline 90 & 1.29 & 1.14 & 1.04 & 0.96 & 90 & 1.87 & 1.68 & 1.55 & 1.46 \\
\hline 100 & 1.43 & 1.26 & 1.15 & 1.06 & 100 & 2.07 & 1.86 & 1.72 & 1.62 \\
\hline 110 & 1.56 & 1.38 & 1.27 & 1.17 & 110 & 2.27 & 2.04 & 1.88 & 1.78 \\
\hline 120 & 1.69 & 1.5 & 1.38 & 1.28 & 120 & 2.46 & 2.22 & 2.05 & 1.94 \\
\hline 130 & 1.84 & 1.64 & 1.49 & 1.39 & 130 & 2.66 & 2.4 & 2.23 & 2.09 \\
\hline 140 & 1.98 & 1.76 & 1.6 & 1.5 & 140 & 2.85 & 2.58 & 2.4 & 2.25 \\
\hline 150 & 2.12 & 1.88 & 1.71 & 1.6 & 150 & 3.04 & 2.75 & 2.56 & 2.41 \\
\hline 160 & 2.25 & 2 & 1.82 & 1.7 & 160 & 3.25 & 2.94 & 2.73 & 2.56 \\
\hline 170 & 2.38 & 2.12 & 1.93 & 1.81 & 170 & 3.44 & 3.12 & 2.9 & 2.71 \\
\hline 180 & 2.52 & 2.24 & 2.04 & 1.91 & 180 & 3.63 & 3.3 & 3.06 & 2.89 \\
\hline 190 & 2.65 & 2.36 & 2.17 & 2.02 & 190 & 3.82 & 3.48 & 3.23 & 3.04 \\
\hline 200 & 2.78 & 2.48 & 2.28 & 2.12 & 200 & 4.01 & 3.65 & 3.39 & 3.2 \\
\hline 210 & 2.91 & 2.6 & 2.39 & 2.22 & 210 & 4.2 & 3.83 & 3.55 & 3.36 \\
\hline 220 & 3.05 & 2.71 & 2.5 & 2.32 & 220 & 4.39 & 4 & 3.72 & 3.51 \\
\hline 230 & 3.18 & 2.85 & 2.61 & 2.43 & 230 & 4.57 & 4.18 & 3.88 & 3.67 \\
\hline 240 & 3.32 & 2.97 & 2.72 & 2.53 & 240 & 4.76 & 4.35 & 4.06 & 3.82 \\
\hline 250 & 3.45 & 3.09 & 2.83 & 2.65 & 250 & 4.96 & 4.52 & 4.22 & 3.98 \\
\hline 260 & 3.58 & 3.2 & 2.94 & 2.75 & 260 & 5.14 & 4.69 & 4.38 & 4.13 \\
\hline 270 & 3.7 & 3.32 & 3.05 & 2.85 & 270 & 5.33 & 4.86 & 4.55 & 4.29 \\
\hline 280 & 3.83 & 3.44 & 3.16 & 2.96 & 280 & 5.52 & 5.05 & 4.71 & 4.44 \\
\hline 290 & 3.96 & 3.56 & 3.27 & 3.06 & 290 & 5.7 & 5.22 & 4.87 & 4.6 \\
\hline 300 & 4.09 & 3.68 & 3.38 & 3.16 & 300 & 5.88 & 5.39 & 5.03 & 4.75 \\
\hline 310 & 4.22 & 3.79 & 3.49 & 3.27 & 310 & 6.07 & 5.57 & 5.2 & 4.9 \\
\hline 320 & 4.34 & 3.91 & 3.59 & 3.37 & 320 & 6.25 & 5.74 & 5.36 & 5.05 \\
\hline 330 & 4.47 & 4.03 & 3.7 & 3.47 & 330 & 6.43 & 5.91 & 5.52 & 5.2 \\
\hline 340 & 4.59 & 4.14 & 3.81 & 3.57 & 340 & 6.61 & 6.08 & 5.68 & 5.37 \\
\hline 350 & 4.72 & 4.26 & 3.93 & 3.67 & 350 & 6.79 & 6.25 & 5.84 & 5.53 \\
\hline 360 & 4.86 & 4.37 & 4.04 & 3.78 & 360 & 6.97 & 6.42 & 6 & 5.68 \\
\hline 370 & 4.98 & 4.49 & 4.15 & 3.88 & 370 & 7.14 & 6.59 & 6.16 & 5.83 \\
\hline 380 & 5.11 & 4.6 & 4.26 & 3.98 & 380 & 7.32 & 6.75 & 6.32 & 5.99 \\
\hline 390 & 5.23 & 4.71 & 4.36 & 4.08 & 390 & 7.52 & 6.92 & 6.47 & 6.14 \\
\hline 400 & 5.36 & 4.84 & 4.47 & 4.18 & 400 & 7.7 & 7.09 & 6.63 & 6.29 \\
\hline
\end{tabular}

Continued Table (1): Guide to the design of furrow irrigation

\begin{tabular}{|c|c|c|c|c|c|c|c|c|c|}
\hline $\mathrm{IF}=2$ & & Qo(lit/s) & & & $\mathrm{IF}=3$ & & Qo(lit/s) & & \\
\hline$L(m)$ & $\mathrm{Zr}=.05 \mathrm{~m}$ & $\mathrm{Zr}=.075 \mathrm{~m}$ & $\mathrm{Zr}=.1 \mathrm{~m}$ & $\mathrm{Zr}=.125 \mathrm{~m}$ & $\mathrm{~L}(\mathrm{~m})$ & $\mathrm{Zr}=.05 \mathrm{~m}$ & $\mathrm{Zr}=.075 \mathrm{~m}$ & $\mathrm{Zr}=.1 \mathrm{~m}$ & $\mathrm{Zr}=.125 \mathrm{~m}$ \\
\hline 20 & 0.54 & 0.5 & 0.45 & 0.43 & 20 & 0.8 & 0.72 & 0.68 & 0.63 \\
\hline 30 & 0.83 & 0.74 & 0.69 & 0.65 & 30 & 1.2 & 1.09 & 1.01 & 0.96 \\
\hline 40 & 1.1 & 1 & 0.92 & 0.87 & 40 & 1.58 & 1.44 & 1.35 & 1.27 \\
\hline 50 & 1.37 & 1.24 & 1.15 & 1.08 & 50 & 1.97 & 1.8 & 1.69 & 1.6 \\
\hline 60 & 1.63 & 1.48 & 1.38 & 1.29 & 60 & 2.35 & 2.16 & 2.01 & 1.92 \\
\hline 70 & 1.9 & 1.73 & 1.61 & 1.52 & 70 & 2.72 & 2.5 & 2.35 & 2.23 \\
\hline 80 & 2.16 & 1.97 & 1.83 & 1.73 & 80 & 3.09 & 2.85 & 2.68 & 2.54 \\
\hline 90 & 2.42 & 2.21 & 2.05 & 1.94 & 90 & 3.47 & 3.2 & 3.01 & 2.85 \\
\hline 100 & 2.68 & 2.44 & 2.28 & 2.16 & 100 & 3.84 & 3.55 & 3.34 & 3.18 \\
\hline 110 & 2.93 & 2.68 & 2.51 & 2.37 & 110 & 4.21 & 3.89 & 3.66 & 3.49 \\
\hline 120 & 3.2 & 2.91 & 2.73 & 2.57 & 120 & 4.57 & 4.23 & 3.98 & 3.8 \\
\hline 130 & 3.45 & 3.16 & 2.95 & 2.78 & 130 & 4.94 & 4.57 & 4.31 & 4.11 \\
\hline 140 & 3.71 & 3.4 & 3.17 & 3.01 & 140 & 5.3 & 4.9 & 4.64 & 4.41 \\
\hline 150 & 3.96 & 3.63 & 3.39 & 3.22 & 150 & 5.66 & 5.25 & 4.96 & 4.72 \\
\hline 160 & 4.21 & 3.86 & 3.61 & 3.43 & 160 & 6.01 & 5.59 & 5.28 & 5.03 \\
\hline 170 & 4.45 & 4.1 & 3.83 & 3.64 & 170 & 6.36 & 5.93 & 5.6 & 5.33 \\
\hline 180 & 4.7 & 4.33 & 4.04 & 3.85 & 180 & 6.71 & 6.26 & 5.91 & 5.65 \\
\hline 190 & 4.96 & 4.56 & 4.28 & 4.05 & 190 & 7.06 & 6.59 & 6.23 & 5.95 \\
\hline 200 & 5.2 & 4.78 & 4.5 & 4.26 & 200 & 7.42 & 6.92 & 6.54 & 6.26 \\
\hline 210 & 5.45 & 5.02 & 4.71 & 4.47 & 210 & 7.77 & 7.25 & 6.86 & 6.56 \\
\hline 220 & 5.69 & 5.25 & 4.93 & 4.67 & 220 & 8.11 & 7.58 & 7.18 & 6.87 \\
\hline 230 & 5.94 & 5.48 & 5.15 & 4.88 & 230 & 8.46 & 7.9 & 7.5 & 7.17 \\
\hline 240 & 6.18 & 5.71 & 5.36 & 5.08 & 240 & 8.8 & 8.24 & 7.81 & 7.47 \\
\hline 250 & 6.42 & 5.94 & 5.58 & 5.29 & 250 & 9.14 & 8.57 & 8.13 & 7.77 \\
\hline 260 & 6.66 & 6.16 & 5.79 & 5.51 & 260 & 9.48 & 8.89 & 8.44 & 8.07 \\
\hline 270 & 6.89 & 6.39 & 6.01 & 5.71 & 270 & 9.82 & 9.22 & 8.75 & 8.37 \\
\hline 280 & 7.13 & 6.62 & 6.22 & 5.92 & 280 & 10.15 & 9.54 & 9.06 & 8.67 \\
\hline 290 & 7.38 & 6.84 & 6.43 & 6.13 & 290 & 10.5 & 9.86 & 9.37 & 8.96 \\
\hline 300 & 7.62 & 7.06 & 6.64 & 6.33 & 300 & 10.84 & 10.18 & 9.68 & 9.26 \\
\hline 310 & 7.86 & 7.29 & 6.86 & 6.53 & 310 & 11.17 & 10.5 & 9.99 & 9.57 \\
\hline 320 & 8.09 & 7.51 & 7.08 & 6.74 & 320 & 11.51 & 10.82 & 10.29 & 9.87 \\
\hline 330 & 8.33 & 7.73 & 7.3 & 6.94 & 330 & 11.84 & 11.14 & 10.6 & 10.17 \\
\hline 340 & 8.56 & 7.96 & 7.51 & 7.15 & 340 & 12.17 & 11.46 & 10.9 & 10.46 \\
\hline 350 & 8.79 & 8.18 & 7.72 & 7.35 & 350 & 12.5 & 11.77 & 11.2 & 10.76 \\
\hline 360 & 9.03 & 8.41 & 7.93 & 7.55 & 360 & 12.83 & 12.1 & 11.52 & 11.05 \\
\hline 370 & 9.26 & 8.63 & 8.14 & 7.75 & 370 & 13.16 & 12.42 & 11.83 & 11.35 \\
\hline 380 & 9.49 & 8.85 & 8.35 & 7.95 & 380 & 13.48 & 12.73 & 12.13 & 11.64 \\
\hline 390 & 9.72 & 9.07 & 8.56 & 8.16 & 390 & 13.81 & 13.05 & 12.44 & 11.94 \\
\hline 400 & 9.95 & 9.29 & 8.77 & 8.36 & 400 & 14.13 & 13.36 & 12.74 & 12.23 \\
\hline
\end{tabular}




\section{REFERENCES}

[1] Ostad-Ali-Askari, K., Shayannejad, M. 2015, Study of sensitivity of Autumnal wheat to under irrigation in Shahrekord, Shahrekord City, Iran. International Journal of Agriculture and Crop Sciences, 8 (4), 602-605.

[2] Shayannejad, M., Akbari, N., Ostad-Ali-Askari, K. 2015, Study of modifications of the river physical specifications on muskingum coefficients, through employment of genetic algorithm. International Journal of Development Research, 5(3), 3782-3785.

[3] Ostad-Ali-Askari, K., Shayannejad, M. 2015, The Reviews of Einstein's Equation of Logarithmic Distribution Platform and the Process of Changes in the Speed Range of the Karkheh River, Khuzestan province, Iran. International Journal of Development Research, 5(3), 3786-3790.

[4] Ostad-Ali-Askari, K., Shayannejad, M., Ghorbanizadee-Kharazi, H. 2015, Assessment of artificial neural network performance and exponential regression in prediction of effective rainfall, International Journal of Development Research, 5(3),3791-3794.

[5] Shayannejad, M. Akbari, N. and Ostad-Ali-Askari, K. 2015, Determination of the nonlinear Muskingum model coefficients using genetic algorithm and numerical solution of the continuity. Int. J. of Science: Basic and Applied Research, 21(1),1-14.

[6] Ostad-Ali-Askari, K., Shayannejad, M. 2015, The Study of Mixture Design for Foam Bitumen and the Polymeric and Oil Materials Function in Loose Soils Consolidation. Journal of Civil Engineering Research, 5(2), 39-44. DOI: 10.5923/j.jce.20150502.04

[7] Sayedipour, M., Ostad-Ali-Askari, K., Shayannejad, M. 2015, Recovery of Run off of the Sewage Refinery, a Factor for Balancing the Isfahan-Borkhar Plain Water Table in Drought Crisis Situation in Isfahan Province-Iran. American Journal of Environmental Engineering, 5(2): 43-46. DOI: 10.5923/j.ajee.20150502.02

[8] Ostad-Ali-Askari, K., Shayannejad, M. 2015, Developing an Optimal Design Model of Furrow Irrigation Based on the Minimum Cost and Maximum Irrigation Efficiency. International Bulletin of Water Resources \& Development, 3(2), 18-23.

[9] Ostad-Ali-Askari K. Groundwater. Horoufchin publisher, First Edition, 2015. ISBN: 978-600-7419-33-5. Isfahan, Iran.

[10] Shayannejad M, Ostad-Ali-Askari K. Modeling of solute movement in groundwater. Kankash publisher. First edition, 2015. ISBN: 978-600-136-256-9. Isfahan, Iran.

[11] Shayannejad M, Ostad-Ali-Askari K. Optimization and its application in water resources management. Kankash publisher. First edition, 2015. ISBN: 978-600-136-248-4. Isfahan, Iran.

[12] Ostad-Ali-Askari K. Nitrate pollution in groundwater. Horoufchin publisher, First Edition, 2015. ISBN: 978-600-7419-23-6. Isfahan, Iran.

[13] Ostad-Ali-Askari, K., Shayannejad, M. 2015, Presenting a Mathematical Model for Estimating the Deep Percolation Due to Irrigation. International Journal of Hydraulic Engineering, 4(1), 17-21. DOI: 10.5923/j.ijhe.20150401.03.

[14] Ostad-Ali-Askari, K., Shayannejad, M. 2015, Usage of rockfill dams in the HEC-RAS software for the purpose of controlling floods. American Journal of Fluid Dynamics, 5(1), 23-29. DOI: 10.5923/j.ajfd.20150501.03.

[15] Ostad-Ali- Askari, K., Shayannejad, M. 2015, The effect of heterogeneity due to inappropriate tillage on water advance and recession in furrow irrigation. Journal of Agricultural Science, 7(6), 127-136.

[16] Shayannejad, M., Ostad-Ali-Askari, K. 2015, Effects of magnetized municipal effluent on some chemical properties of soil in furrow irrigation. International Journal of Agriculture and Crop Sciences, 8(3), 482489.

[17] Ostad-Ali-Askari K, Shayannejad M, Golabchian M. Numerical methods in groundwater. Kankash publisher. First edition, 2015. ISBN: 978-600-136-276-7. Isfahan, Iran.

[18] Ostad-Ali-Askari, K., Shayannejad, M. 2015, Optimal design of pressurized irrigation laterals installed on sloping land. International Journal of Agriculture and Crop Sciences, ISSN 2227-670X. 8(5), 792-797.

[19] Ostad-Ali-Askari K, Shayannejad M, Eslamian S, Jahangiri A.K, Shabani A.H, Environmental Hydraulics of Open Channel Flows. Kankash Publisher. First Edition, 2015. ISBN: 978-600-136-303-0.

[20] Ostad-Ali-Askari K, Shayannejad M, Eslamian S, Navab-Pour B. 2016, Comparison of solution of SaintVenant equations by characteristics and finite difference methods for unsteady flow analyzing in open channel. International Journal of Hydrology Science and Technology, 6(3), 9-18.

[21] Ostad-Ali-Askari K, Shayannejad M, Eslamian S, et al. 2017, Deficit Irrigation: Optimization Models. Management of Drought and Water Scarcity. Handbook of Drought and Water Scarcity, Taylor \& Francis Publisher, USA. Vol. 3. $1^{\text {th }}$ Edition, pp: 373-389. 
[22] Eskandari S, Hoodaji M, Tahmourespour A, Abdollahi A, Mohammadian-Baghi T, Eslamian S, Ostad-AliAskari K. 2017, Bioremediation of Polycyclic Aromatic Hydrocarbons by Bacillus Licheniformis ATHE9 and Bacillus Mojavensis ATHE13 as Newly Strains Isolated from Oil-Contaminated Soil. Journal of Geography, Environment and Earth Science International, 11(2): 1-11.

[23] Shayannejad M, Ostad-Ali-Askari K, Eslamian S, et al. 2017, Development of a new method for determination of infiltration coefficients in furrow irrigation with natural non-uniformity of slope. Sustain. Water Resour. Manag., 3(2): 163-169.

[24] Shojaei N, Shafaei-Bejestan M, Eslamian S, Marani-Barzani M, P. Singh V, Kazemi M, Ostad-Ali-Askari K. 2017, Assessment of Drainage Slope on the Manning Coarseness Coefficient in Mountain Area. International Journal of Constructive Research in Civil Engineering (IJCRCE), 3(1): 33-40.

[25] Bahmanpour H, Awhadi S, Enjili J, Eslamian S, Ostad-Ali-Askari K. 2017, Optimizing Absorbent Bentonite and Evaluation of Contaminants Removal from Petrochemical Industries Wastewater. International Journal of Constructive Research in Civil Engineering (IJCRCE), 3(2): 34-42.

[26] Shayannejad M, Eslamian S, Gandomkar A, Marani-Barzani M, Amoushahi-Khouzani M, Majidifar Z, Rajaei-Rizi F, Kazemi M, P. Singh V, Dehghan SH, Shirvani-Dastgerdi H.R, Norouzi H, Ostad-Ali-Askari K. 2017, A Proper Way to Install Trapezoidal Flumes for Measurements in Furrow Irrigation Systems. International Journal of Research Studies in Agricultural Sciences (IJRSAS), 3(7): 1-5.

[27] Dehghan Sh, Kamaneh S.A.A., Eslamian S, Gandomkar A, Marani-Barzani M, Amoushahi-Khouzani M, Singh V.P., Ostad-Ali-Askari K. 2017, Changes in Temperature and Precipitation with the Analysis of Geomorphic Basin Chaos in Shiraz, Iran. International Journal of Constructive Research in Civil Engineering (IJCRCE), 3(2): 50-57.

[28] Eslamian S, Mirabbasi-Najafabadi R, Ostad-Ali-Askari K. Advance Engineering Statistics (Simulation and Modeling of Uncertainty and Sensitivity Analysis). Kankash Publisher. First Edition, 2017. ISBN: 978600-136-359-7. Isfahan, Iran.

[29] Ostad-Ali-Askari K, Shayannejad M. 2016, FLOOD ROUTING IN RIVERS BY MUSKINGUM'S METHOD WITH NEW ADJUSTED COEFFICIENTS. International Water Technology Journal, IWTJ, 6(3): 189-194.

[30] Godarzi A, Eslamian S, Ostad-Ali-Askari K. Water in Literature Aspects (Social and Cultural Aspects). Publication of Tehran Municipality. First Edition, 2016. ISBN: 978-600-439-096-5. Tehran, Iran.

[31] Ostad-Ali-Askari K, Eslamian S, Shayannejad M, et al. Groundwater Hydrodynamic. Horoufchin Publisher. First Edition, 2016. ISBN: 978-600-7419-53-3. Isfahan, Iran.

[32] Ostad-Ali-Askari K, Shayannejad M, Ghorbanizadeh-Kharazi H. 2017, Artificial Neural Network for Modeling Nitrate Pollution of Groundwater in Marginal Area of Zayandeh-rood River, Isfahan, Iran. KSCE Journal of Civil Engineering, 21(1):134-140. Korean Society of Civil Engineers. DOI 10.1007/s12205-016-0572-8.

[33] Shayannejad M, Ostad-Ali-Askari K, Ramesh A, Singh V.P., Eslamian S. 2017, Wastewater and Magnetized Wastewater Effects on Soil Erosion in Furrow Irrigation. International Journal of Research Studies in Agricultural Sciences (IJRSAS), 3(8): 1-14. http://dx.doi.org/10.20431/2454-6224.0308001.

[34] Shayannejad M, Soltani-Toudeshki A.R, Arab M.A, Eslamian S, Amoushahi-Khouzani M, MaraniBarzani M, Ostad-Ali-Askari K. 2017, A Simple Method for Land Grading Computations and its Comparison with Genetic Algorithm (GA) Method. International Journal of Research Studies in Agricultural Sciences (IJRSAS), 3(8): 26-38.

[35] Mohieyimen P, Eslamian S, Ostad-Ali-Askari K, Soltani M. 2017,Climate Variability: Integration of Renewable Energy into Present and Future Energy Systems in Designing Residential Buildings. International journal of Rural Development, Environment and Health Research(IJREH), 1(2): 18-30.

[36] Shayannejad M, Ostad-Ali-Askari K, Eslamian S, et al. 2017, Flow Hydraulic Investigation of the Wastewater on the Soil and Magnetic Field Effects in This Field. International Journal of Constructive Research in Civil Engineering (IJCRCE), 3(3): 1-15.

[37] Dalezios, N. R., Tarquis Alfonso, A. M., and Eslamian, S., 2017, Drought Assessment and Risk Analysis, Ch. 18 in Handbook of Drought and Water Scarcity, Vol. 1: Principles of Drought and Water Scarcity, Ed. by Eslamian S. and Eslamian F., Francis and Taylor, CRC Press, USA, 323-344.

[38] Dalezios, N. R., Spyropoulosand, N. V., Eslamian, S., 2017, Remote Sensing in Drought Quantification and Assessment, Ch. 21 in Handbook of Drought and Water Scarcity, Vol. 1: Principles of Drought and Water Scarcity, Ed. by Eslamian S. and Eslamian F., Francis and Taylor, CRC Press, USA, 377-396.

[39] Araghinejad, S., Hosseini-Moghari, S. M., Eslamian, S., 2017, Application of Data-Driven Models in Drought Forecasting, Ch. 23 in Handbook of Drought and Water Scarcity, Vol. 1: Principles of Drought and Water Scarcity, Ed. by Eslamian S. and Eslamian F., Francis and Taylor, CRC Press, USA, 423-440. 
[40] Vafakhah, M., and Eslamian, S., 2017, Application of Intelligent Technology in Rainfall Analysis, Ch. 24 in Handbook of Drought and Water Scarcity, Vol. 1: Principles of Drought and Water Scarcity, Ed. by Eslamian S. and Eslamian F., Francis and Taylor, CRC Press, USA, 441-460.

[41] Vafakhah, M., Akbari Majdar, H. and Eslamian, S., 2017, Rainfall Prediction Using Time Series Analysis, Ch. 28 in Handbook of Drought and Water Scarcity, Vol. 1: Principles of Drought and Water Scarcity, Ed. by Eslamian S. and Eslamian F., Francis and Taylor, CRC Press, USA, 517-540.

[42] González, M. H., Garbarini, E. M., Rolla, A. L., and Eslamian, S., 2017, Meteorological Drought Indices: Rainfall Prediction in Argentina, Ch. 29 in Handbook of Drought and Water Scarcity, Vol. 1: Principles of Drought and Water Scarcity, Ed. by Eslamian S. and Eslamian F., Francis and Taylor, CRC Press, USA, 541-570.

[43] Hadizadeh, R. and Eslamian, S., 2017, Modeling Hydrological Process by ARIMA-GARCH Time Series, Ch. 30 in Handbook of Drought and Water Scarcity, Vol. 1: Principles of Drought and Water Scarcity, Ed. by Eslamian S. and Eslamian F., Francis and Taylor, CRC Press, USA, 571-590.

[44] Mujere, N., Yang, X. and Eslamian, S., 2017, Gradation of Drought-Prone Area, Ch. 31 in Handbook of Drought and Water Scarcity, Vol. 1: Principles of Drought and Water Scarcity, Ed. by Eslamian S. and Eslamian F., Francis and Taylor, CRC Press, USA, 591-606.

[45] Mahmudul Haque, M., Amir Ahmed, A., Rahman, A., Eslamian, S., 2017, Drought Losses to Local Economy, Ch. 33 in Handbook of Drought and Water Scarcity, Vol. 1: Principles of Drought and Water Scarcity, Ed. by Eslamian S. and Eslamian F., Francis and Taylor, CRC Press, USA, 627-642.

[46] Fakhruddin, B. S. H. M., Eslamian, S., 2017, Analysis of Drought Factors Affecting the Economy, Ch. 34 in Handbook of Drought and Water Scarcity, Vol. 1: Principles of Drought and Water Scarcity, Ed. by Eslamian S. and Eslamian F., Francis and Taylor, CRC Press, USA, 643-656.

[47] Dalezios, N. R., Eslamian, S., 2017, Environmental Impacts of Drought on Desertification Classification, Ch. 3 in Handbook of Drought and Water Scarcity, Vol. 2: Environmental Impacts and Analysis of Drought and Water Scarcity, Ed. by Eslamian S. and Eslamian F., Francis and Taylor, CRC Press, USA, 45-64.

[48] Nazif, S. and Tavakolifar, H., Eslamian, S., 2017, Climate Change Impact on Urban Water Deficit, Ch. 5 in Handbook of Drought and Water Scarcity, Vol. 2: Environmental Impacts and Analysis of Drought and Water Scarcity, Ed. by Eslamian S. and Eslamian F., Francis and Taylor, CRC Press, USA, 81-106.

[49] Shahid, S., Alamgir, M., Wang, X.-J., Eslamian, S., 2017, Climate Change Impacts on and Adaptation to Groundwater, Ch. 6 in Handbook of Drought and Water Scarcity, Vol. 2: Environmental Impacts and Analysis of Drought and Water Scarcity, Ed. by Eslamian S. and Eslamian F., Francis and Taylor, CRC Press, USA, 107-124.

[50] Orimoogunje, O. O. I., Eslamian, S., 2017, Minimizing the Impacts of Drought, Ch. 8 in Handbook of Drought and Water Scarcity, Vol. 2: Environmental Impacts and Analysis of Drought and Water Scarcity, Ed. by Eslamian S. and Eslamian F., Francis and Taylor, CRC Press, USA, 143-162.

[51] Maleksaeidi, H., Keshavarz, M., Karami, E., Eslamian, S., 2017, Climate Change and Drought: Building Resilience for an Unpredictable Future, Ch. 9 in Handbook of Drought and Water Scarcity, Vol. 2: Environmental Impacts and Analysis of Drought and Water Scarcity, Ed. by Eslamian S. and Eslamian F., Francis and Taylor, CRC Press, USA, 163-186.

[52] Reyhani, M. N., Eslamian, S., Davari, A., 2017, Sustainable Agriculture: Building Social-Ecological Resilience, Ch. 10 in Handbook of Drought and Water Scarcity, Vol. 2: Environmental Impacts and Analysis of Drought and Water Scarcity, Ed. by Eslamian S. and Eslamian F., Francis and Taylor, CRC Press, USA, $187-204$.

[53] Crusberg, T. C., Eslamian, S., 2017, Drought and Water Quality, Ch. 11 in Handbook of Drought and Water Scarcity, Vol. 2: Environmental Impacts and Analysis of Drought and Water Scarcity, Ed. by Eslamian S. and Eslamian F., Francis and Taylor, CRC Press, USA, 205-218.

[54] Gaaloul, N., Eslamian, S., and Laignel, B., 2017, Contamination of Groundwater in Arid and Semiarid Lands, Ch. 16 in Handbook of Drought and Water Scarcity, Vol. 2: Environmental Impacts and Analysis of Drought and Water Scarcity, Ed. by Eslamian S. and Eslamian F., Francis and Taylor, CRC Press, USA, 291-314.

[55] Banjoko, B., Eslamian, S., 2017, Sanitation in Drought, Ch. 17 in Handbook of Drought and Water Scarcity, Vol. 2: Environmental Impacts and Analysis of Drought and Water Scarcity, Ed. by Eslamian S. and Eslamian F., Francis and Taylor, CRC Press, USA, 315-330.

[56] Davari, A., Bagheri, A., Reyhani, M. N., Eslamian, S., 2017, Environmental Flows Assessment in Scarce Water Resources, Ch. 18 in Handbook of Drought and Water Scarcity, Vol. 2: Environmental Impacts and Analysis of Drought and Water Scarcity, Ed. by Eslamian S. and Eslamian F., Francis and Taylor, CRC Press, USA, 331-352. 
[57] Qian, Q., Eslamian, S., 2017, Streamflow Quality in Low-Flow Conditions, Ch. 20 in Handbook of Drought and Water Scarcity, Vol. 2: Environmental Impacts and Analysis of Drought and Water Scarcity, Ed. by Eslamian S. and Eslamian F., Francis and Taylor, CRC Press, USA, 375-386.

[58] Mohammadzade Miyab, N., Eslamian, S., Dalezios, N. R., 2017, River Sediment in Low Flow Condition, Ch. 21 in Handbook of Drought and Water Scarcity, Vol. 2: Environmental Impacts and Analysis of Drought and Water Scarcity, Ed. by Eslamian S. and Eslamian F., Francis and Taylor, CRC Press, USA, 387-408.

[59] Pérez-Blanco, C. D., Delacámara., G., Gómez., C. M., Eslamian, S., 2017, Crop Insurance in Drought Conditions, Ch. 23 in Handbook of Drought and Water Scarcity, Vol. 2: Environmental Impacts and Analysis of Drought and Water Scarcity, Ed. by Eslamian S. and Eslamian F., Francis and Taylor, CRC Press, USA, 423-444.

[60] Kahrizi, D., Esfahani, K., Ashraf Mehrabi, A., Ghaheri, M., Azizi Aram, Z., Khosravi, S., Eslamian, S., 2017, Biotechnology for Drought Improvement, Ch. 24 in Handbook of Drought and Water Scarcity, Vol. 2: Environmental Impacts and Analysis of Drought and Water Scarcity, Ed. by Eslamian S. and Eslamian F., Francis and Taylor, CRC Press, USA, 445-460.

[61] Wade, P., Eslamian, S., 2017, Water Issues from a System Dynamics Perspective, Ch. 25 in Handbook of Drought and Water Scarcity, Vol. 2: Environmental Impacts and Analysis of Drought and Water Scarcity, Ed. by Eslamian S. and Eslamian F., Francis and Taylor, CRC Press, USA, 461-488.

[62] Rahman, A., Hajani, E., Eslamian, S., 2017, Rainwater Harvesting in Arid Regions of Australia, Ch. 26 in Handbook of Drought and Water Scarcity, Vol. 2: Environmental Impacts and Analysis of Drought and Water Scarcity, Ed. by Eslamian S. and Eslamian F., Francis and Taylor, CRC Press, USA, 489-500.

[63] Mukherjee, S., Yadav, K., Eslamian, S., 2017, Soil Contaminations in Arid and Semiarid Land, Ch. 29 in Handbook of Drought and Water Scarcity, Vol. 2: Environmental Impacts and Analysis of Drought and Water Scarcity, Ed. by Eslamian S. and Eslamian F., Francis and Taylor, CRC Press, USA, 547-556.

[64] Dayani, S., Sabzalian, M. R., Hadipour, M. Eslamian, S., 2017, Water Scarcity and Sustainable Urban Green Landscape, Ch. 30 in Handbook of Drought and Water Scarcity, Vol. 2: Environmental Impacts and Analysis of Drought and Water Scarcity, Ed. by Eslamian S. and Eslamian F., Francis and Taylor, CRC Press, USA, 557-604.

[65] Gohari, A., Zareian, M. J., Eslamian, S., Nazari, R. 2017, Interbasin Transfers of Water: Zayandeh-Rud River Basin, Ch. 32 in Handbook of Drought and Water Scarcity, Vol. 2: Environmental Impacts and Analysis of Drought and Water Scarcity, Ed. by Eslamian S. and Eslamian F., Francis and Taylor, CRC Press, USA, 619-630.

[66] Banjoko, B., Eslamian, S., 2017, Environmental Evaluation: Lessons Learned from Case Studies, Ch. 33 in Handbook of Drought and Water Scarcity, Vol. 2: Environmental Impacts and Analysis of Drought and Water Scarcity, Ed. by Eslamian S. and Eslamian F., Francis and Taylor, CRC Press, USA, 631-664.

[67] Abbasova, D., Eslamian, S., Nazari, R., 2017, Paleo-Drought: Measurements and Analysis, Ch. 34 in Handbook of Drought and Water Scarcity, Vol. 2: Environmental Impacts and Analysis of Drought and Water Scarcity, Ed. by Eslamian S. and Eslamian F., Francis and Taylor, CRC Press, USA, 665-674.

[68] Yihdego, Y., Eslamian, S., 2017, Drought Management: Initiatives and Objectives, Ch. 1 in Handbook of Drought and Water Scarcity, Vol. 3: Management of Drought and Water Scarcity, Ed. by Eslamian S. and Eslamian F., Francis and Taylor, CRC Press, USA, 1-26.

[69] Tuncok, I. K., Eslamian, S., 2017, Drought Management Strategies in Water-Stressed/Water-Scarce Regions, Ch. 5 in Handbook of Drought and Water Scarcity, Vol. 3: Management of Drought and Water Scarcity, Ed. by Eslamian S. and Eslamian F., Francis and Taylor, CRC Press, USA, 97-154.

[70] Reinstädtler, S., Islam, S. N., Eslamian, S., 2017, Drought Management for Landscape and Rural Security, Ch. 8 in Handbook of Drought and Water Scarcity, Vol. 3: Management of Drought and Water Scarcity, Ed. by Eslamian S. and Eslamian F., Francis and Taylor, CRC Press, USA, 195-234.

[71] Dalezios, N. R., Eslamian, S., 2017, Drought Assessment and Management for Heat Waves Monitoring, Ch. 9 in Handbook of Drought and Water Scarcity, Vol. 3: Management of Drought and Water Scarcity, Ed. by Eslamian S. and Eslamian F., Francis and Taylor, CRC Press, USA, 235-260.

[72] Kruse, E., Eslamian, S., 2017, Groundwater Management in Drought Conditions, Ch. 11 in Handbook of Drought and Water Scarcity, Vol. 3: Management of Drought and Water Scarcity, Ed. by Eslamian S. and Eslamian F., Francis and Taylor, CRC Press, USA, 275-282.

[73] Araghinejad, S., Hosseini-Moghari, S.-M., Eslamian, S., 2017, Reservoir Operation during Drought, Ch. 12 in Handbook of Drought and Water Scarcity, Vol. 3: Management of Drought and Water Scarcity, Ed. by Eslamian S. and Eslamian F., Francis and Taylor, CRC Press, USA, 283-292.

[74] Eslamian, S., Khosravi, B., Sayahi, M., Haeri-Hamedani, M. 2017, Crises Management Planning and Drought Management Plans, Ch. 13 in Handbook of Drought and Water Scarcity, Vol. 3: Management of Drought and Water Scarcity, Ed. by Eslamian S. and Eslamian F., Francis and Taylor, CRC Press, USA, 293-304. 
[75] Halbac-Cotoara-Zamfir, R., Eslamian, S., 2017, Functional Analysis of Regional Drought Management, Ch. 14 in Handbook of Drought and Water Scarcity, Vol. 3: Management of Drought and Water Scarcity, Ed. by Eslamian S. and Eslamian F., Francis and Taylor, CRC Press, USA, 305-328.

[76] Zahraei, A., Saadati, S., Eslamian, S., 2017, Irrigation Deficit: Farmlands, Ch. 16 in Handbook of Drought and Water Scarcity, Vol. 3: Management of Drought and Water Scarcity, Ed. by Eslamian S. and Eslamian F., Francis and Taylor, CRC Press, USA, 343-358.

[77] Amiri, M. J., Eslamian, S., Bahrami, M., Yousefi, N. 2017, Deficit Irrigation: Greenhouse, Ch. 17 in Handbook of Drought and Water Scarcity, Vol. 3: Management of Drought and Water Scarcity, Ed. by Eslamian S. and Eslamian F., Francis and Taylor, CRC Press, USA, 359-372.

[78] Ostad-Ali-Askari, K., Shayanejad, M., Eslamian, S., Zamani, F., Shojaei, N., Navabpour, B., Majidifard, Z., Sadri, A., Ghasemi-Siani, Z., Nourozi, H., Vafaei, O., Homayouni. S.-M.-A., 2017, Deficit Irrigation: Optimization Models, Ch. 18 in Handbook of Drought and Water Scarcity, Vol. 3: Management of Drought and Water Scarcity, Ed. by Eslamian S. and Eslamian F., Francis and Taylor, CRC Press, USA, 373-390.

[79] Eludoyin, A. O., Eludoyin, O. M., Eslamian, S., 2017, Drought Mitigation Practices, Ch. 19 in Handbook of Drought and Water Scarcity, Vol. 3: Management of Drought and Water Scarcity, Ed. by Eslamian S. and Eslamian F., Francis and Taylor, CRC Press, USA, 391-402

[80] Irshad, S. M., Eslamian, S., 2017, Politics of Drought Management and Water Control in India, Ch. 22 in Handbook of Drought and Water Scarcity, Vol. 3: Management of Drought and Water Scarcity, Ed. by Eslamian S. and Eslamian F., Francis and Taylor, CRC Press, USA, 447-460.

[81] Pati, R., Eslamian, S., 2017, Drought Management for Horticultural Crops in India, Ch. 23 in Handbook of Drought and Water Scarcity, Vol. 3: Management of Drought and Water Scarcity, Ed. by Eslamian S. and Eslamian F., Francis and Taylor, CRC Press, USA, 461-482.

[82] Khan, S., Eslamian, S., 2017, Ch. 25 in Handbook of Drought and Water Scarcity, Vol. 3: Management of Drought and Water Scarcity, Ed. by Eslamian S. and Eslamian F., Francis and Taylor, CRC Press, USA, 495-526.

[83] Sedaei, L., Sedaei, N., Cox, J. P., Dalezios N. R., Eslamian, S., 2017, Forest Fire Mitigation under Water Shortage, Ch. 26 in Handbook of Drought and Water Scarcity, Vol. 3: Management of Drought and Water Scarcity, Ed. by Eslamian S. and Eslamian F., Francis and Taylor, CRC Press, USA, 527-550.

[84] Torabi Farsani, N., Neto de Carvalho, C., Eslamian, S., 2017, Education Program for Drought, Ch. 27 in Handbook of Drought and Water Scarcity, Vol. 3: Management of Drought and Water Scarcity, Ed. by Eslamian S. and Eslamian F., Francis and Taylor, CRC Press, USA, 551-566.

[85] Nazif, S. and Tavakolifar, H., Eslamian, S., 2017, Emergency Drought Consequence Plan, Ch. 30 in Handbook of Drought and Water Scarcity, Vol. 3: Management of Drought and Water Scarcity, Ed. by Eslamian S. and Eslamian F., Francis and Taylor, CRC Press, USA, 640-658

[86] Mohseni Saravi, M., Shabazi, R., Eslamian, S., 2017, Coping with Drought- Ch. 31 in Handbook of Drought and Water Scarcity, Vol. 3: Management of Drought and Water Scarcity, Ed. by Eslamian S. and Eslamian F., Francis and Taylor, CRC Press, USA, 659-673

[87] Eslamian, S., Mohri-Isfahani, E., Mahdavi, A., Rajaei-Rizi, F., Marzi-Nouhedani, M., Ghasemi-Zanyani, M., Dehghani, S., Hosseini-Teshnizi., S. Z., Esmaeili, F., Shojaei, N., Ghane, M., Hasantabar-Amiri, A., 2017, Integrated Water Resources Management Under Water Scarcity, Ch. 32 in Handbook of Drought and Water Scarcity, Vol. 3: Management of Drought and Water Scarcity, Ed. by Eslamian S. and Eslamian F., Francis and Taylor, CRC Press, USA, 675-695.

[88] Aghaei, A., Eslamian, S., Dalezios, N. R., Saeidi-Rizi, A., Bahrebardar, S., 2017, Drought and Dust Management, Ch. 33 in Handbook of Drought and Water Scarcity, Vol. 3: Management of Drought and Water Scarcity, Ed. by Eslamian S. and Eslamian F., Francis and Taylor, CRC Press, USA, 696.

[89] Eslamian, S., Dalezios, N. R., Singh, V. P., Adamowaski, J., Mohamadifard, S., Bahmani, R., Eskandari, S., Zomorodian, M., Arefeyan, A., Dehghani, S., Aghaesmaeili, M., Shahbazi, M., Amoushahi, M. T., Yousefi, N., Namdi, A., 2017, Drought Management: Current Challenges and Future Outlook, Ch. 34 in Handbook of Drought and Water Scarcity, Vol. 3: Management of Drought and Water Scarcity, Ed. by Eslamian S. and Eslamian F., Francis and Taylor, CRC Press, USA.

[90] Eslamian, S., Davari, A., and Reyhani, M. N., 2017, Iranian Qanāts: An Ancient and Sustainable Water Resources Utilization, Ch. 9, in Underground Aqueducts Handbook, Ed. By Angelakis A. N. et al., Taylor and Francis, CRC Group, 123-150.

[91] Khan, S., and Eslamian , S., 2017, Managing Drought through Qanāt and Water Conservation in Afghanistan, Ch. 22, in Underground Aqueducts Handbook, Ed. By Angelakis A. N. et al., Taylor and Francis, CRC Group, 385-402.

[92] Wessels, J. I., Vardakos, S., Weingartner, H., Eslamian, S., Angelakis, A. N., 2017, Underground Aqueducts: Past, Present, and Future Trends, Ch. 29 in Underground Aqueducts Handbook, Ed. By Angelakis A. N. et al., Taylor and Francis, CRC Group, 491-510. 
[93] Dalezios, N.R., Tarquis, A. M. and Eslamian, S. 2017: Droughts. Chapter 5, in book: Environmental Hazards Methodologies for Risk Assessment and Management. Editor: Dalezios, N. R., International Water Association Publishing, London, UK, 177-210.

[94] Dalezios, N. R. and Eslamian, S, 2017, Environmental Hazards Methodologies for Risk Assessment and Management, Ed. By Dalezios, N. R., IWA Publishing,

[95] Bazrkar, M. H., Adamowski, J., Eslamian, S., 2017, Water System Modeling, in Mathematical Advances Towards Sustainable Environmental Systems, Ed. by Furze, J.N., Swing, K., Gupta, A.K., McClatchey, R., Reynolds, D., Springer International Publishing, Switzerland, 61-88.

[96] Zareeian, M.J., Eslamian, S., Gohari, A., and Adamowski, J. 2017. The Effect of Climate Change on Watershed Water Balance, in Mathematical Advances Towards Sustainable Environmental Systems, Ed. by Furze, J.N., Swing, K., Gupta, A.K., McClatchey, R., Reynolds, D., Springer International Publishing, Switzerland, 215-238.

[97] Bazrkar, M. H., Zamani, N., Eslamian, S., Eslamian, A., Dehghan, Z., 2015, Urbanization and Climate Change, Handbook of Climate Change Adaptation, Ed. By Leal Filho, W., Springer, 619-655.

[98] Gohari, A., Zareeian, M. J. and Eslamian, S., 2015, A multi-model framework for climate change impact assessment, Handbook of Climate Change Adaptation, Ed. By Leal Filho, W., Springer, 17-35.

[99] Chen, Z., Ngo, H. H., Guo,W, and Eslamian, S., 2015, Water Shortages, in Urban Water Reuse Handbook, Ch. 1, Ed. By Eslamian, S., Taylor and Francis, CRC Group, USA, 3-14.

[100]Boogaard, F. and Eslamian, S., 2015, Water Reuse and Sustainable Urban Drainage Systems, in Urban Water Reuse Handbook, Ch. 4, Ed. By Eslamian, S., Taylor and Francis, CRC Group, USA, 37-44.

[101]Shah Naqvi, S. A. A., Sultan, A., and Eslamian, S., 2015, Water Quality Issues in Urban Water, in Urban Water Reuse Handbook, Ch. 8, Ed. By Eslamian, S., Taylor and Francis, CRC Group, USA, 99-112.

[102]Kumar Singh, Ch., Jha, N., and Eslamian, S., 2015, Reuse, Potable Water, and Possibilities, in Urban Water Reuse Handbook, Ch. 9, Ed. By Eslamian, S., Taylor and Francis, CRC Group, USA, 113-126.

[103]Kohansal, M. M., Saadati, S., Tarkesh Esfahany, S., and Eslamian, S., 2015, Urban Water Reuse in Industry, in Urban Water Reuse Handbook, Ch. 11, Ed. By Eslamian, S., Taylor and Francis, CRC Group, USA, 137-148.

[104]Kumar, M., Chidambaram, S., Ramanathan, A. L., Goswami, R., and Eslamian, S., 2015, Criterion, Indices, and Classification of Water Quality and Water Reuse Options, Urban Water Reuse Handbook, Ch. 13, Ed. By Eslamian, S., Taylor and Francis, CRC Group, USA, 163-176.

[105]Eslamian, F., Eslamian, S., and Eslamian, A., 2015, Water Reuse Guidelines for Agriculture, Urban Water Reuse Handbook, Ch. 14, Ed. By Eslamian, S., Taylor and Francis, CRC Group, USA, 177-186.

[106]Eslamian, A., Eslamian, F., and Eslamian, S., 2015, Water Reuse Guidelines for Industry, Urban Water Reuse Handbook, Ch. 15, Ed. By Eslamian, S., Taylor and Francis, CRC Group, USA, 187-194.

[107]Eslamian, S., Eslamian, F., and Eslamian, A., 2015, Water Reuse Guidelines for Recreation, Urban Water Reuse Handbook, Ch. 16, Ed. By Eslamian, S., Taylor and Francis, CRC Group, USA, 195-200.

[108]Banjoko, B. and Eslamian, S., 2015, Environmental Impact Assessment: An Application to Urban Water Reuse, Urban Water Reuse Handbook, Ch. 20, Ed. By Eslamian, S., Taylor and Francis, CRC Group, USA, 229-242.

[109]Amiri, M. J., Eslamian, S., Arshadi, M., and Khozaei, M., 2015, Water Recycling and Community, Urban Water Reuse Handbook, Ch. 22, Ed. By Eslamian, S., Taylor and Francis, CRC Group, USA, 261-274.

[110]Ferdaush, J., Noor Islam, Sh., Reinstädtler, S., and Eslamian, S., 2015, Ethical and Cultural Dimension of Water Reuse, Urban Water Reuse Handbook, Ch. 24, Ed. By Eslamian, S., Taylor and Francis, CRC Group, 285-296.

[111]Bazrkar, M. H., Zamani, N., and Eslamian, S., 2015, Evaluation of Socioeconomic Impacts of Urban Water Reuse Using System Dynamics Approach, Urban Water Reuse Handbook, Ch. 28, Ed. By Eslamian, S., Taylor and Francis, CRC Group, 331-340.

[112]Mujere, N. and Eslamian, S., 2015, Blackwater System, Urban Water Reuse Handbook, Ch. 33, Ed. By Eslamian, S., Taylor and Francis, CRC Group, 393-404.

[113]Abu-Ghunmi, L., and Eslamian, S., 2015, Graywater, Urban Water Reuse Handbook, Ch. 34, Ed. By Eslamian, S., Taylor and Francis, CRC Group, 405-420.

[114]Eslamian, S., Amininezhad, S. M., and Amininejad, S. M., 2015, Contamination Warning System, Urban Water Reuse Handbook, Ch. 39, Ed. By Eslamian, S., Taylor and Francis, CRC Group, 481-488.

[115]Crusberg, T. C., and Eslamian, S., 2015, Choosing Indicators of Fecal Pollution for Wastewater Reuse Opportunities, Urban Water Reuse Handbook, Ch. 42, Ed. By Eslamian, S., Taylor and Francis, CRC Group, 511-520. 
[116]Boogaard, F. and Eslamian, S, 2015, Wastewater Monitoring, Urban Water Reuse Handbook, Ch. 48, Ed. By Eslamian, S., Taylor and Francis, CRC Group, 583-586.

[117]Mujere, N., and Eslamian, S., 2015, Urban Wetland Hydrology and Water Purification, Urban Water Reuse Handbook, Ch. 50, Ed. By Eslamian, S., Taylor and Francis, CRC Group, 603-616.

[118]Nazif, S., and Eslamian , S., 2015, Urban Wetland Hydrology and Changes , Urban Water Reuse Handbook, Ch. 51, Ed. By Eslamian, S., Taylor and Francis, CRC Group, 617-640.

[119]Banjoko, B., and Eslamian, S., 2015, Phytoremediation, Urban Water Reuse Handbook, Ch. 53, Ed. By Eslamian, S., Taylor and Francis, CRC Group, 657-702.

[120]Rivas Hernández, A., Rivas Acosta, I., and Eslamian, S., .2015, Treatment Wetlands: Fundamentals, Urban Water Reuse Handbook, Ch. 54, Ed. By Eslamian, S., Taylor and Francis, CRC Group, 703-716.

[121]Rahman, A., and Eslamian, S., 2015, Rainwater Tanks as a Means of Water Reuse and Conservation in Urban Areas, Urban Water Reuse Handbook, Ch. 60, Ed. By Eslamian, S., Taylor and Francis, CRC Group, 797-808.

[122]Qian, Q., and Eslamian, S., 2015, Groundwater Recharge and Unconventional Water: Design and Management Criteria, Urban Water Reuse Handbook, Ch. 61, Ed. By Eslamian, S., Taylor and Francis, CRC Group, 809-816.

[123] Saket, R. K. and Eslamian, S., 2015, Use of Wastewater for Hydroelectric Power Generation, Urban Water Reuse Handbook, Ch. 63, Ed. By Eslamian, S., Taylor and Francis, CRC Group, 827-838.

[124]Eslamian, S., Amininezhad, S. M., Amininejad, S. M., Adamowski, J., 2015, Application of Nanotechnology in Water Reuse, Urban Water Reuse Handbook, Ch. 64, Ed. By Eslamian, S., Taylor and Francis, CRC Group, 839-844.

[125]Goodarzi, E., Ziaei, L. and Eslamian, S., 2015, Recycled Water in Basin and Farm Scales, Urban Water Reuse Handbook, Ch. 65, Ed. By Eslamian, S., Taylor and Francis, CRC Group, 855-858.

[126]Perez Sierra, J. A. and Eslamian, S., 2015, Water Reuse in Coastal Areas, Urban Water Reuse Handbook, Ch. 67, Ed. By Eslamian, S., Taylor and Francis, CRC Group, 867-874.

[127]Noor Islam, Sh., Reinstädtler, S., and Eslamian, S., 2015, Water Reuse Sustainability in Cold Climate Regions, Urban Water Reuse Handbook, Ch. 68, Ed. By Eslamian, S., Taylor and Francis, CRC Group, 875-886.

[128]Rina, K., Eslamian, S., Tyagi, G., and Singh, N., 2015, Feasibility Studies for Water Reuse Systems, Urban Water Reuse Handbook, Ch. 71, Ed. By Eslamian, S., Taylor and Francis, CRC Group, 909, 926.

[129]Salequzzaman, MD., Tariqul Islam, S. M., Shiddi quzzaman, M., and Eslamian, S., 2015. Climate Change Adaptation and Water Reuse, Urban Water Reuse Handbook, Ch. 75, Ed. By Eslamian, S., Taylor and Francis, CRC Group, 969-980.

[130]Kumar Goyal, M., Singh, V., and Eslamian, S., 2015, Impact of Climate Change on Drinking Water, Urban Water Reuse Handbook, Ch. 76, Ed. By Eslamian, S., Taylor and Francis, CRC Group, 981-1006.

[131]Hamdy, A. and Eslamian, S., 2015, Sustainable Reuse and Recycling of Treated Urban Wastewater, Urban Water Reuse Handbook, Ch. 80, Ed. By Eslamian, S., Taylor and Francis, CRC Group, 1039-1054.

[132]Thakur, J. K., Karmacharya, S., Singh, P., Gurung, D., and Eslamian, S., 2015, Water Reuse Products in Urban Areas, Urban Water Reuse Handbook, Ch. 81, Ed. By Eslamian, S., Taylor and Francis, CRC Group, 1055-1070.

[133]Eslamian, S., Sayahi, M., and Khosravi, B., 2015, Conjunctive Use of Water Reuse and Urban Water, Urban Water Reuse Handbook, Ch. 82, Ed. By Eslamian, S., Taylor and Francis, CRC Group, 1071-1078.

[134] Irfan, Z. B., and Eslamian, S., 2015, Urban Water Reuse Policy, Urban Water Reuse Handbook, Ch. 83, Ed. By Eslamian, S., Taylor and Francis, CRC Group, 1079-1096.

[135]Vafakhah, M., Eslamian, S. and Khosrobeigi Bozchaloei, S., 2014, Low-Flow Hydrology, in Handbook of Engineering Hydrology, Ch. 20, Vol. 1: Fundamentals and Applications, Ed. By Eslamian, S., Francis and Taylor, CRC Group, USA, 433-453.

[136]Cox, J. P., Shaeri Karimi, S. and Eslamian, S., 2014, Optimum Hydrometric Site Selection, in Handbook of Engineering Hydrology, Ch. 22, Vol. 1: Fundamentals and Applications, Ed. By Eslamian, S., Francis and Taylor, CRC Group, USA, 471-483.

[137]Eslamian, S. and Motevallian, S. S., 2014, Sustainability in Urban Water System, in Handbook of Engineering Hydrology, Ch. 27, Vol. 1: Fundamentals and Applications, Ed. By Eslamian, S., Francis and Taylor, CRC Group, USA, 549-562.

[138]Noor Islam, S., Karim, R., Noor Islam, A., and Eslamian, S., 2014, Wetland Hydrology, in Handbook of Engineering Hydrology, Ch. 29, Vol. 1: Fundamentals and Applications, Ed. By Eslamian, S., Francis and Taylor, CRC Group, USA, 581-605. 
[139]Gargouri-Ellouze, E. and Eslamian, S. 2014, Application of Copulas in Hydrology: Geomorphological Instantaneous Unit Hydrograph and Intensity Index of Infiltration Frequency, in Handbook of Engineering Hydrology, Ch. 1, Vol. 2: Modeling, Climate Changes and Variability, Ed. By Eslamian, S., Francis and Taylor, CRC Group, USA, 1-18.

[140]Mujere, N. and Eslamian, S. 2014, Climate Change Impacts on Hydrology and Water Resources, in Handbook of Engineering Hydrology, Ch. 7, Vol. 2: Modeling, Climate Changes and Variability, Ed. By Eslamian, S., Francis and Taylor, CRC Group, USA, 113-126.

[141]Farzaneh, M. R., Eslamian, S. and Mirnezami, S. J. E. 2014, Climate Change: Uncertainty, Impact, and Adaptation, in Handbook of Engineering Hydrology, Ch. 8, Vol. 2: Modeling, Climate Changes and Variability, Ed. By Eslamian, S., Francis and Taylor, CRC Group, USA, 127-146.

[142] Goodarzi, E. and Eslamian, S. 2014, Dam Risk and Uncertainty, in Handbook of Engineering Hydrology, Ch. 9, Vol. 2: Modeling, Climate Changes and Variability, Ed. By Eslamian, S., Francis and Taylor, CRC Group, USA, 147-171.

[143]Fakhri, M., Dokohaki, H., Eslamian, S., Fazeli Farsani, I. and Farzaneh, M. R. 2014, Flow and Sediment Transport Modeling in Rivers, in Handbook of Engineering Hydrology, Ch. 13, Vol. 2: Modeling, Climate Changes and Variability, Ed. By Eslamian, S., Francis and Taylor, CRC Group, USA, 233-275.

[144]Matouq, M., Al-Bilbisi, H., El-Hasan, T. and Eslamian, S. 2014, GIS Applications in a Changing Climate, in Handbook of Engineering Hydrology, Ch. 15, Vol. 2: Modeling, Climate Changes and Variability, Ed. By Eslamian, S., Francis and Taylor, CRC Group, USA, 297-312.

[145]Noor Islam, S., Gnauck, A., Voigt, H.-J. and Eslamian, S., 2014, Hydrological Changes in Mangrove Ecosystems, in Handbook of Engineering Hydrology, Ch. 18, Vol. 2: Modeling, Climate Changes and Variability, Ed. By Eslamian, S., Francis and Taylor, CRC Group, USA, 353-373.

[146]Kałuża, T. and Eslamian, S. 2014, Impact of the Development of Vegetation on Flow Conditions and Flood Hazards, in Handbook of Engineering Hydrology, Ch. 21, Vol. 2: Modeling, Climate Changes and Variability, Ed. By Eslamian, S., Francis and Taylor, CRC Group, USA, 415-449.

[147]Rahman, A., Haddad, Kh. and Eslamian, S., 2014, Regional Flood Frequency Analysis, 2014, in Handbook of Engineering Hydrology, Ch. 22, Vol. 2: Modeling, Climate Changes and Variability, Ed. By Eslamian, S., Francis and Taylor, CRC Group, USA, 451-469.

[148]Vafakhah, M. and Eslamian, S. 2014, Regionalization of Hydrological Variables, in Handbook of Engineering Hydrology, Ch. 23, Vol. 2: Modeling, Climate Changes and Variability, Ed. By Eslamian, S., Francis and Taylor, CRC Group, USA, 471-499.

[149]Chowdhury, R. K. and Eslamian, S. 2014, Statistical Parameters Used for Assessing Hydrological Regime, in Handbook of Engineering Hydrology, Ch. 26, Vol. 2: Modeling, Climate Changes and Variability, Ed. By Eslamian, S., Francis and Taylor, CRC Group, USA, 537-551.

[150]Mujere, N. and Eslamian, S. 2014, Impact of Urbanization on Runoff Regime, Chowdhury, R. K. and Eslamian, S. 2014, Statistical Parameters Used for Assessing Hydrological Regime, in Handbook of Engineering Hydrology, Ch. 29, Vol. 2: Modeling, Climate Changes and Variability, Ed. By Eslamian, S., Francis and Taylor, CRC Group, USA, 605-615.

[151]Gaaloul, N. and Eslamian, S., 2014, Artificial Recharge Experiences in Semiarid Areas, in Handbook of Engineering Hydrology, Ch. 2, Vol. 3: Environmental Hydrology and Water Management, Ed. By Eslamian, S., Francis and Taylor, CRC Group, USA, 17-49.

[152]Amininezhad, S. M., Amininejad, S. M., and Eslamian, S., 2014, Disinfection of Water and Nanotechnology, in Handbook of Engineering Hydrology, Ch. 3, Vol. 3: Environmental Hydrology and Water Management, Ed. By Eslamian, S., Francis and Taylor, CRC Group, USA, 51-64.

[153]Shaeri Karimi, S., Yasi, M., Cox, J. P., and Eslamian, S., 2014, Environmental Flows, in Handbook of Engineering Hydrology, Ch. 5, Vol. 3: Environmental Hydrology and Water Management, Ed. By Eslamian, S., Francis and Taylor, CRC Group, USA, 85-104.

[154]Eslamian, S., Malekian, R., and Amiri, M. J. 2014, Environmental Nanotechnology, in Handbook of Engineering Hydrology, Ch. 6, Vol. 3: Environmental Hydrology and Water Management, Ed. By Eslamian, S., Francis and Taylor, CRC Group, USA, 105-118.

[155]Deiminiat, A., and Eslamian, S., 2014, River Managed System for Flood Defense, in Handbook of Engineering Hydrology, Ch. 14, Vol. 3: Environmental Hydrology and Water Management, Ed. By Eslamian, S., Francis and Taylor, CRC Group, USA, 299-314.

[156]Deiminiat, A., Hassan Shojaee Siuki, and Eslamian, S. 2014, Tourism and River Environment, in Handbook of Engineering Hydrology, Ch. 20, Vol. 3: Environmental Hydrology and Water Management, Ed. By Eslamian, S., Francis and Taylor, CRC Group, USA, 401-419. 
[157]Green, C. and Eslamian, S., 2014, Water Governance, in Handbook of Engineering Hydrology, Ch. 24, Vol. 3: Environmental Hydrology and Water Management, Ed. By Eslamian, S., Francis and Taylor, CRC Group, USA, 461-483.

[158]Eslamian, F. and Eslamian S., 2014, Water Pollution Control Using Low-Cost Natural Wastes, in Handbook of Engineering Hydrology, Ch. 25, Vol. 3: Environmental Hydrology and Water Management, Ed. By Eslamian, S., Francis and Taylor, CRC Group, USA, 485-499.

[159]He, Ch., Zhang, L., Zhang, X., and Eslamian, S., 2014, Water Security: Concept, Measurement, and Operationalization, in Handbook of Engineering Hydrology, Ch. 28, Vol. 3: Environmental Hydrology and Water Management, Ed. By Eslamian, S., Francis and Taylor, CRC Group, USA, 545-554.

[160]Fakhri, M., Farzaneh, M. R., Eslamian S. and Nazari, R., 2013, Wind speed regionalization under climate change conditions, Chapter 10, New Developments in Renewable Energy by H. Arman \& I. Yukcel, 215236.

[161]Nazari, R., Khanbilvardi, R., Hoyos, S., and Eslamian, S., 2013, Freshwater Demands and Storages, Encyclopedia of Crises Management, Sage Publication.

[162]Eslamian, S., 2012, Forecasting, Encyclopedia of Energy, Salem Press, USA, 461-464

[163]Eslamian, S., 2012, Iran, Encyclopedia of Energy, Salem Press, USA, 708-713.

[164]Eslamian, S. and Nazari, R., 2012, Nebraska, Encyclopedia of Energy, Salem Press, USA, 889-893.

[165]Nazari, R., S. Eslamian and R. Khanbilvardi, 2012, Water Reuse and Sustainability, Chapter 11, in Ecological Water Quality-Water Treatment and Reuse by K. Voudouris and D. Vousta, 241-254, Intech.

[166]Eslamian, S. S., Gilroy K. L. and R. H. McCuen, 2011, Climate Change Detection and Modeling in Hydrology, Ch. 5 in "Climate Change -Research and Technology for Adaptation and Mitigation" Edited by J. Blanco and H. Kheradmand, InTech, 87-100.

[167]Shayannejad, M., Vanani, H.R., Tudeshki, A.R.S., Ostad-Ali-Askari, K., Eslamian, S., Mohri-Esfahani, E., Haeri-Hamedani, M. and Jabbari, H., 2017. Development of a new method for determination of infiltration coefficients in furrow irrigation with natural non-uniformity of slope. Sustainable Water Resources Management, pp.1-7. DOI 10.1007/s40899-017-0091-x.

[168]Zarei, A.R. and Eslamian, S., 2017. Trend assessment of precipitation and drought index (SPI) using parametric and non-parametric trend analysis methods (case study: arid regions of southern Iran). International Journal of Hydrology Science and Technology, Vol. 7, No. 1, 12-38.

[169]Nikzad, J., Eslamian, S. S., Soleymannejad, M. and Karimpour, A, 2016. Numerical solution for onedimensional Richards' equation using differential quadrature method, Current Science, Vol. 111, No. 6, 1028-1036.

[170]Yousefi, N., Khodashenas, S. R., Eslamian, S. and Askari, Z. 2016. Estimating width of the stable channels using multivariable mathematical models, Arab. J. Geosci., Vol. 9, No. 321, DOI 10.1007/s12517-016-2322-0.

[171]Banihabib, M. E., Zahraei, A. and Eslamian, S., 2016. Dynamic Programming Model for the System of a Non- Uniform Deficit Irrigation and a Reservoir. Irrigation and Drainage, Vol. 66, No. 1, 71-81

[172]Zalewski, M., McClain, M. and Eslamian, S., 2016. New challenges and dimensions of Ecohydrologyenhancement of catchments sustainability potential, Ecohydrology and Hydrobiology, 16, 1-3

[173]Zalewski, M., McClain, M. and Eslamian, S., 2016. Ecohydrology-the background for the integrative sustainability science, Ecohydrology and Hydrobiology, No. 16, 71-73.

[174]Kouhestani, S., Eslamian, S.S., Abedi-Koupai, J. and Besalatpour, A.A., 2016. Projection of climate change impacts on precipitation using soft-computing techniques: A case study in Zayandeh-rud Basin, Iran. Global and Planetary Change, No. 144, 158-170.

[175]Teimouri, A., Eslamian, S. and Shabankare, A. 2016. Removal of Heavy Metals from Aqueous Solution by Red Alga Gracilaria Corticata as a New Biosorbent, Trends in Life Science, Vol. 5, No. 1, 236-243.

[176]Amiri, M.J., Hamidifar, H., Bahrami, M. and Eslamian, S. (2016) 'Optimisation of deficit-irrigation under variable seasonal rainfall and planning scenarios for rice in a semi-arid region of Iran', International Journal of Hydrology Science and Technology, Vol. 6, No. 4, 331-343.

[177] Salarijazi, M., Abdolhosseini, M., Ghorbani, K. and Eslamian, S. 2016, Evaluation of quasi-maximum likelihood and smearing estimator to improve sediment rating curve estimation', International Journal of Hydrology Science and Technology, Vol. 6, No. 4, 359-370.

[178]Amiri, M.J., Bahrami, M., Hamidifar, H. and Eslamian, S., 2016. Modification of furrow Manning's roughness coefficient estimation by finite difference technique under surge and continuous flow. International Journal of Hydrology Science and Technology, Vol. 6, No. 3, 226-237.

[179]Zahraei, A., Eslamian, S. and Saadati, S., 2016. The effect of water extraction time from the river on the performance of off-stream reservoirs. International Journal of Hydrology Science and Technology, 6(3): 254-265. 
[180]Zareian, M. J. and Eslamian, S., 2016, Variation of water resources indices in a changing climate, International Journal of Hydrology Science and Technology, Vol. 6, No. 2, 173 - 187.

[181]Fathian, F., Dehghan, Z.., Eslamian, S., Adamowski, J., 2016, Assessing Irrigation Network Performance Based on Different Climate Change and Water Supply Scenarios: A Case Study in Northern Iran, International Journal of Water, Accepted.

[182]Fathian, F., Dehghan, Z.., Eslamian, S., 2016, Evaluating the impact of changes in land cover and climate variability on streamflow trends (case study: eastern subbasins of Lake Urmia, Iran), J. Hydrology Science and Technology, Vol. 6, No. 1, 1-26.

[183]Dalezios, N. R. and Eslamian, S, 2016, Regional design storm of Greece within the flood risk management framework, Int. J. Hydrology Science and Technology, Vol. 6, No. 1, 82-102.

[184]Kamali, M. I., Nazari, R., Fridhosseini, A., Ansari, H., Eslamian, S., 2015, The Determination of Reference Evapotranspiration for Spatial Distribution Mapping Using Geostatistics, Vol. 29: 3929-3940.

[185]Talchabhadel, R., Shakya, N. M. Dahal , V., and Eslamian, S., 2015, Rainfall Runoff Modelling for Flood Forecasting (A Case Study on West Rapti Watershed), Journal of Flood Engineering, Vol. 6, No. 1, 53-61.

[186] Yousefi, N., Safaee, A., Eslamian, S., 2015, The Optimum Design of Flood Control System Using Multivariate Decision Making Methods (Case Study: Kan River Catchment Basin, Iran), Journal of Flood Engineering, Vol. 6, No. 1, 63-82.

[187]Banihabib, M. E., Zahraei, A. and Eslamian, S., 2015, An integrated optimization model of reservoir and irrigation system applying uniform deficit irrigation, Int. J. Hydrology Science and Technology, Vol. 5, No. 4, 372-385.

[188]Fathian, F., Prasad, A. D., Dehghan, Z.., Eslamian, S., 2015, Influence of land use/land cover change on land surface temperature using RS and GIS techniques, Int. J. Hydrology Science and Technology, Vol. 5, No. 3, 195-207.

[189]Abedi-koupai, J., Mollaei, R., Eslamian, S. S., 2015, The effect of pumice on reduction of cadmium uptake by spinach irrigated with wastewater, Ecohydrology and Hydrobiology, Vol. 15, No. 4, 208-214.

[190]Kamali, M. I., Nazari, R., Faridhosseini, A., Ansari, H., Eslamian, S., 2015, The Determination of Reference Evapotranspiration for Spatial Distribution Mapping Using Geostatistics, Water Resources Management, 29:3929-3940.

[191]Valipour, M., Gholami Sefidkouhi, M. A., Eslamian, S., 2015, Surface irrigation simulation models: a review, Int. J. Hydrology Science and Technology, Vol. 5, No. 1, 51-70.

[192]Esmailzadeh, M., Heidarpour, M., Eslamian, S., 2015, Flow characteristics of sharp-crested side sluice gate, ASCE's Journal of Irrigation and Drainage Engineering, Vol. 141, No. 7, 10.1061/(ASCE)IR.19434774.0000852.

[193]Zareian, M. J., Eslamian, S. and Safavi, H. R., 2015, A modified regionalization weighting approach for climate change impact assessment at watershed scale, Theor. Appl. Climatol., 122:497-516.

[194]Boucefiane A., Meddi M., Laborde J. P., Eslamian S. S., 2014, Rainfall Frequency Analysis Using Extreme Values, Distributions in the Steppe Region of Western Algeria, Int. J. Hydrology Science and Technology, Vol. 4, No. 4, 348-367.

[195]Valipour, M., Eslamian, S., 2014, Analysis of potential evapotranspiration using 11 modified temperaturebased models, Int. J. Hydrology Science and Technology, Vol. 4, No. 3, 192-207.

[196]Meddi, M., Toumi, S., Assani, A. A., Eslamian, S., 2014, Regionalization of Rainfall Erosivity in Northern Algeria, Int. J. Hydrology Science and Technology, Vol. 4, No. 2, 155-175.

[197]Zohrabi, N., Massah Bavani, A., Goodarzi, E., S. Eslamian, 2014, Attribution of temperature and precipitation changes to greenhouse gases in northwest Iran, Quaternary International, Vol. 345, 130-137.

[198]Farshad F., Dehghan, Z., Eslamian, S., H. Bazrkar, 2015, Trends in hydrologic and climatic variables affected by four variations of Mann-Kendall approach in Urmia Lake basin, Iran, Hydrological Sciences Journal, DOI:10.1080/02626667.2014.932911.

[199]Fazlolahi, H. and S. S. Eslamian, 2014, Using wetland plants in nutrient removal from municipal wastewater, Int. J. Hydrology Science and Technology, Vol. 4, No. 1, 68-80.

[200]Shayannejad M,Eslamian S,Singh V.P.,Ostad-Ali-Askari K, et al. 2017, Evaluation of Groundwater Quality for Industrial Using GIS in Mountainous Region of Isfahan Province, Koh-Payeh, Isfahan, Iran. International Journal of Constructive Research in Civil Engineering (IJCRCE), 3(3): 24-37.

[201]Eslamian S, P. Singh V, Ostad-Ali-Askari K, R. Dalezios N, Yihdego Y, et al. 2017, Assessment of Aridity Using Geographical Information System in Zayandeh-Roud Basin, Isfahan, Iran. International Journal of Mining Science (IJMS), 3(2): 49-61. 
[202] Askari Z, Samadi-Boroujeni H, Fattahi-Nafchi R, Yousefi N, Eslamian S, Ostad-Ali-Askari K, P. Singh V, R. Dalezios N. 2017, Prediction Comparison of Flow Resistance in Channels with Rounded and Angular Coarse Rough Beds. American Research Journal of Civil And Structural, 3(1): 1-15.

[203] Ghane M, Alvankar S.R., Eslamian S, Amoushahi-Khouzani M, Gandomkar A, Zamani E, Marani-Barzani M, Kazemi M, Soltani M, Dehghan SH, P. Singh V, Ostad-Ali-Askari K, HaeriHamedani M, ShirvaniDastgerdi H.R., Zalaki-Badil N. 2017, Sensitivity Analysis of Runoff Model by SWAT to Meteorological Parameters: A Case Study of Kasillian Watershed, Mazandaran, Iran. International Journal of Research Studies in Agricultural Sciences (IJRSAS), 3(10): 1-20.

[204] Shayannejad M, Abedi M.S., Eslamian S, Ostad-AliAskari K, Gandomkar A, Cheng A, et al. 2017, The Contribution of Artificial Charging in Optimal Exploitation of Water Resources, Isfahan, Iran. InternationalJournal of Mining Science (IJMS), 3(3): 9-20.

\section{AUTHORS' BIOGRAPHY}

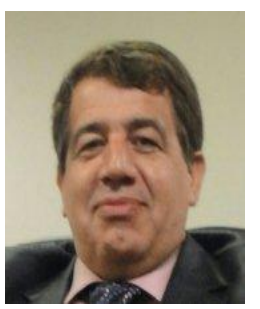

Professor Saeid Eslamian, is a full professor of water system engineering in the Department of Water Engineering at Isfahan University of Technology, Iran, where he has been since 1995. He received his $\mathrm{PhD}$ from Civil and Environmental Engineering School, University of New South Wales, Sydney, Australia, under the supervision of Professor David Pilgrim. His research focuses mainly on water resources planning, management, and sustainability and statistical and environmental hydrology in a changing climate. Formerly, he was a visiting professor at Princeton University, New Jersey, and University of ETH Zurich, Switzerland. On the research side, he started a research partnership in 2014 with McGill University, Montreal, Quebec, Canada. He has contributed to more than 600 publications in journals, books, or as technical reports. $\mathrm{He}$ is the founder and chief editor of both the International Journal of Hydrology Science and Technology (Scopus, Inderscience) and the Journal of Flood Engineering. Professor Eslamian is also associate editor of the Journal of Hydrology (Elsevier) and Ecohydrology and Hydrobiology (Elsevier). He has authored more than 150 book chapters and books. Recently, Professor Eslamian published eight handbooks with Taylor \& Francis Group (CRC Press) as chief editor: a three-volume Handbook of Engineering Hydrology (2014), Urban Water Reuse Handbook (2015), a three-volume Handbook of Drought and Water Scarcity (2017), and Underground Aqueducts Handbook (2016).

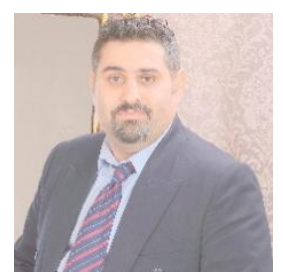

Dr. Kaveh Ostad-Ali-Askari, is a $\mathrm{PhD}$ of civil engineering, Department of Water Resources Engineering, Faculty of Civil Engineering. He collaborates as Editorial Board Membership in more than 45 Journals and as reviewers in more than 35 Journals. Currently, Associate, Editor-in-Chief of IJREH. He has contributed to more than 125 publications in Journals, Books and Technical Reports. He was a Visiting Assistant Professor at Canadian University Dubai, and American University in Dubai. On the research side, he started a research partnership in 2017 with Concordia University in Montreal, Quebec, Canada. His topics of interest include Groundwater Hydrology, Irrigation and Drainage Engineering, Sustainable Development and Environmental Assessment, Climate and Integrated and Sustainable Water Resource Management, Water System Engineering, Water Resources Planning, Artificial Neural Network, and Genetic Algorithm. Currently, he is a Faculty Member of the Department of Civil Engineering, Isfahan(Khorasgan) Branch, Islamic Azad University, Iran.

Mahboubeh Amoushahi-Khouzani, Water Engineering Department, Science and Research Branch, Islamic Azad University, Tehran, Iran.

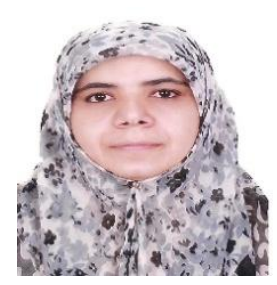

Maryam Marani-Barzani, Department of Geography, University of Malaya (UM),50603 Kuala Lumpur, Malaysia.Member of Suggestion Committee in Ministerial of Education in Iran(2002-2007).Member of Research on Heat Sink Capability of Inland Water Resources for Thermal Power Plants in Peninsular Malaysiaproject (TNBR)(2014-2015).Member of Board Trustees at Consultant Engineering Company (SharsazanZendeh Rood) in Iran.(2015-peresent). 


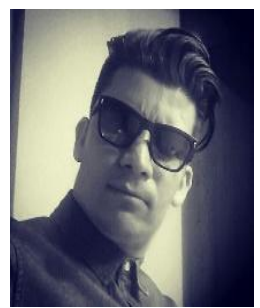

Morteza Soltani, Department of Architectural Engineering, Shahinshahr Branch, Islamic Azad University, Shahinshahr, Iran.

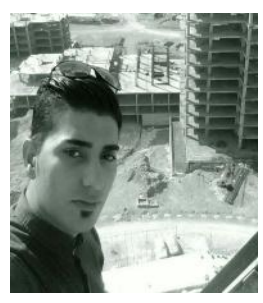

Masoud Kazemi, M.Sc. student of Civil Engineering, Civil Engineering Department, Najafabad Branch, Islamic Azad University, Iran.He has been an expert in various projects of Civil Engineering and technical software such as AutoCAD and MATLAB ${ }^{\circledR}$ programming

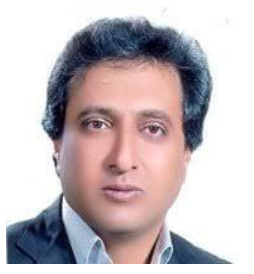

Dr. Amir Gandomkar, Department of Geography, Najafabad Branch, Islamic Azad University, Najafabad, Iran.

Shahide Dehghan, Department of Geography, Najafabad Branch, Islamic Azad University, Najafabad, Iran.

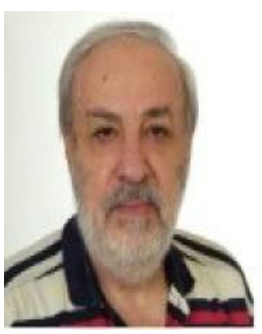

Nicolas R. Dalezios, is a professor of agro-meteorology and remote sensing, University of Thessaly, Volos Hellas; president of the Council of the Agricultural University of Athens, Hellas; and professor and founding director of the Laboratory of Agro-meteorology, University of Thessaly, Volos Hellas (1991-2011). He has done his postgraduate studies in meteorology (Athens, 1972) and hydrological engineering (University of Delft, 1974) and his $\mathrm{PhD}$ in civil engineering (University of Waterloo, Canada, 1982). He has a longstanding research record in agro-meteorology, agro-hydrology, remote sensing, modeling, environmental hazards, risk assessment, climate variability/change. He is the author or co-author in over 280 refereed publications and technical and scientific publications, member of editorial boards and reviewer in international scientific journals, editor or co-editor in over 15 edited publications, and co-author in about 30 book chapters.

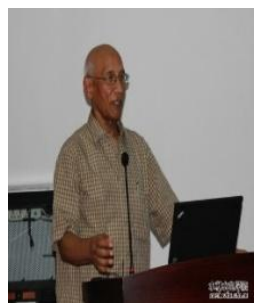

Professor Vijay P. Singh, Ph.D., D.Sc., D. Eng. (Hon.), Ph.D. (Hon.), D.Sc. (Hon.), P.E., P.H., Hon. D. WRE, Academician (GFA), Distinguished Professor, Regents Professor, Caroline and William N. Lehrer Distinguished Chair in Water Engineering

President, FARA, President, G.B.S. Board, Editor-in-Chief, Water Science and Technology Library Bookseries, Editor, Global Water Resources Book Series, Editor-in-Chief, Journal of Ground Water Research, Editor-in-Chief, Open Agriculture, Editor, Journal of Agricultural Research, Department of Biological and Agricultural Engineering \& Zachry Department of Civil Engineering, Texas A and M University. is a professor of agro-meteorology and remote sensing, University of Thessaly, Volos Hellas; president of the Council of the Agricultural University of Athens, Hellas; and professor and founding director of the Laboratory of Agro-meteorology, University of Thessaly, Volos Hellas (1991-2011). He has done his postgraduate studies in meteorology (Athens, 1972) and hydrological engineering (University of Delft, 1974) and his PhD in civil engineering (University of Waterloo, Canada, 1982). He has a longstanding research record in agro-meteorology, agro-hydrology, remote sensing, modeling, environmental hazards, risk assessment, climate variability/change. He is the author or co-author in over 290 refereed publications and technical and scientific publications, member of editorial boards and reviewer in international scientific journals, editor or co-editor in over 20 edited publications, and co-author in about 35 book chapters. 


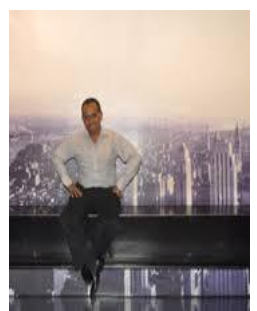

Dr. Yohannes Yihdego, Snowy Mountains Engineering Corporation (SMEC), Sydney, New South Wales 2060, Australia. Geo Information Science and Earth Observation (ITC), University of Twente, the Netherlands.

Working at Global Engineering consulting firm in Hydro-Geo-Engineering across Australia, Middle East, Asia, Africa in water, resource, mining, infrastructure, transport, energy, agriculture, landfill, contamination/pollution/remediation, environmental assessments, flood/urban drainage design/modelling, drought, climate change Produced hundreds' of Engineering technical -feasibility/ detail design reports \& Published several articles \& book chapters Serving as peer Reviewer \& Editor board member.

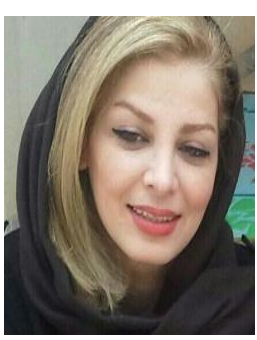

Foroozan Rajaei-Rizi, Water Engineering Department, Shahrekord University, Shahrekord, Iran.

Hossein Norouzi, Department of Civil Engineering, Maybod Branch, Islamic Azad University, Maybod, Yazd, Iran.

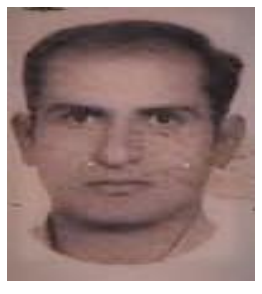

Hamid-Reza Shirvani-Dastgerdi, Department of Civil Engineering, Isfahan (Khorasgan) Branch, Islamic Azad University, Isfahan, Iran.

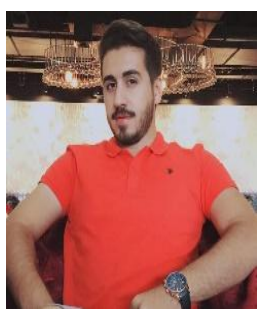

Arvin Jamshidi, Department of Civil Engineering, Isfahan (Khorasgan) Branch, Islamic Azad University, Isfahan, Iran.

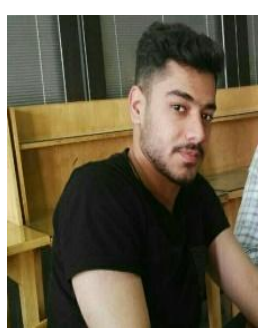

Arsalan Malekian, Department of Civil Engineering, Isfahan (Khorasgan) Branch, Islamic Azad University, Isfahan, Iran.

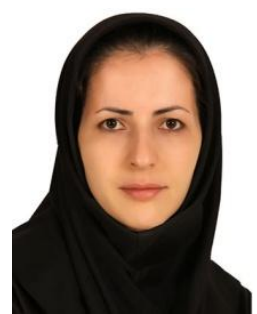

Zahra Majidifar, Department of Agronomy and Plant Breeding, Lorestan University, Lorestan, Iran.

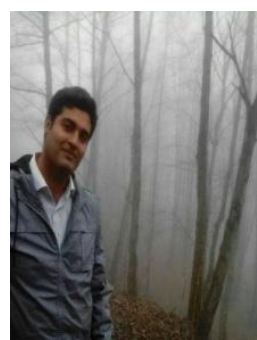

Mohsen Ghane, Civil Engineering Department, South Tehran Branch, Islamic Azad University,Tehran,Iran. 
Citation: Kaveh Ostad-Ali-Askari et al. (2017) Guidelines to Optimal Design of Furrow Irrigation Based on Plants, Soil and Furrow Specifications, International Journal of Constructive Research in Civil Engineering, 3(4), pp.20-39. DOI: http://dx.doi.org/10.20431/2454-8693.0304003

Copyright: () 2017: Kaveh Ostad-Ali-Askari. This is an open-access article distributed under the terms of the Creative Commons Attribution License, which permits unrestricted use, distribution, and reproduction in any medium, provided the original author and source are credited. 